\title{
Spatial and Temporal Trends in Precambrian Nitrogen Cycling: A Mesoproterozoic Offshore Nitrate Minimum
}

\section{Citation}

Koehler, Matthew, Eva Stüeken, Michael Kipp, Roger Buick, and Andrew Knoll. 2017. Spatial and Temporal Trends in Precambrian Nitrogen Cycling: A Mesoproterozoic Offshore Nitrate Minimum. Geochimica Et Cosmochimica Acta 198, no. C: 315-337.

\section{Permanent link}

http://nrs.harvard.edu/urn-3:HUL.InstRepos:41275725

\section{Terms of Use}

This article was downloaded from Harvard University's DASH repository, and is made available under the terms and conditions applicable to Open Access Policy Articles, as set forth at http:// nrs.harvard.edu/urn-3:HUL.InstRepos:dash.current.terms-of-use\#OAP

\section{Share Your Story}

The Harvard community has made this article openly available. Please share how this access benefits you. Submit a story.

Accessibility 
a Mesoproterozoic offshore nitrate minimum

3

1. Department of Earth \& Space Sciences and Astrobiology Program, University of Washington,

8 Box 351310, Seattle WA 98195, USA

9 2. Department of Earth Sciences, University of California, Riverside, CA 92521, USA

10 3. Department of Earth \& Environmental Sciences, University of St Andrews, St Andrews KY16

11 9AL, Scotland, UK

12 4. Department of Organismic and Evolutionary Biology, Harvard University, Cambridge, MA,

1302138

$14 *$ corresponding author (koehlerm@uw.edu)

16 Abstract

17 Fixed nitrogen is an essential nutrient for eukaryotes. As $\mathrm{N}_{2}$ fixation and assimilation of

18 nitrate are catalyzed by metalloenzymes, it has been hypothesized that in Mesoproterozoic

19 oceans nitrate was limited in offshore environments by low trace metal concentrations and high

20 rates of denitrification in anoxic and episodically euxinic deep water masses, restricting

21 eukaryotes to near-shore environments and limiting their evolutionary innovation. To date this

22 hypothesis has only been tested in the Belt Supergroup ( 1.4 Ga), with results that support an

23 onshore-offshore nitrate gradient as a potential control on eukaryote ecology. Here we present 
24 bulk nitrogen and organic carbon isotopic data from non-isochronous cross-basinal facies across

25 the Bangemall ( 1.5 Ga) and the Roper ( 1.4-1.5 Ga) basins to better understand the extent and

26 variability of onshore-offshore nitrogen isotope gradients in the Mesoproterozoic. Both basins

27 show an average $\sim 1-2 \%$ enrichment in $\delta^{15} \mathrm{~N}_{\text {bulk }}$ from deep to shallow facies, with a maximum

28 range from $-1 \%$ offshore to $+7.5 \%$ onshore. Unlike the Belt basin, the Bangemall and Roper

29 basins show some offshore $\delta^{15} \mathrm{~N}_{\text {bulk }}$ values that are enriched beyond the isotopic range induced

30 by biological $\mathrm{N}_{2}$ fixation alone. This suggests a mixture of aerobic and anaerobic metabolisms

31 offshore. In shallow waters, where $\delta^{15} \mathrm{~N}_{\text {bulk }}$ enrichment peaks, an aerobic nitrogen cycle was

32 evidently operating vigorously. Even though isotopic signatures of aerobic nitrogen cycling are

33 seen in all parts of the Bangemall and Roper basins, our data are consistent with a lateral gradient

34 in nitrate availability within the photic zone, with higher concentrations in near-shore

35 environments than offshore. The variability in $\delta^{15} \mathrm{~N}_{\text {bulk }}$ values in each depositional environment

36 and the consistently low $\delta^{15} \mathrm{~N}$ values from Mesoproterozoic units compared to the

37 Paleoproterozoic and Neoproterozoic suggest that nitrate concentrations in the global ocean were

38 likely low. This trend is now seen in all three Mesoproterozoic basins so far examined, and

39 contrasts with the Paleoproterozoic and Neoproterozoic where nearly all $\delta^{15} \mathrm{~N}_{\text {bulk }}$ data plot above

40 the $\mathrm{N}_{2}$ fixation window. Thus, we propose that the Mesoproterozoic ocean was characterized by

41 a nitrate minimum between the Paleo- and Neoproterozoic, with the lowest concentrations in

42 offshore environments. This inference is consistent with a Mesoproterozoic $\mathrm{O}_{2}$ decline following

43 a temporary Paleoproterozoic $\mathrm{O}_{2}$ peak, and it further supports the idea that nitrate limitation

44 offshore may have contributed to the restriction of photosynthetic eukaryotes to near-shore

45 environments, delaying their rise to ecological dominance until the Neoproterozoic Era. 


\section{Introduction}

Fixed nitrogen, including nitrate and ammonium, is an essential nutrient for eukaryotes.

49 Its limitation by certain chemical conditions may have exerted spatial control on eukaryotic

50 diversity and abundance to such an extent (Anbar and Knoll, 2002) that it repressed the

51 evolutionary radiation of eukaryotic primary producers prior to the Neoproterozoic "second rise

52 of oxygen.” Consistent with this hypothesis, Javaux et al., (2001) found that eukaryotic

53 microfossil diversity and abundance in the Mesoproterozoic Roper basin were greater in marine

54 marginal and inner shelf environments than in outer shelf and basinal settings. Buick and Knoll

55 (1999) found a similar trend in acritarchs and prokaryotic microfossils in the Mesoproterozoic

56 Bangemall basin, noting a decrease in taxonomic diversity and numerical abundance offshore.

57 Contemporaneous with these observed microfossil trends are geochemical data in the form of

58 iron-sulfur systematics, Mo and $\mathrm{Cr}$ abundances, and sulfur isotopic ratios that suggest that the

59 Mesoproterozoic ocean was characterized by more widespread anoxia and notably more euxinia

60 than any other time after the Great Oxidation Event (Canfield, 1998; Shen et al., 2002; Arnold et

61 al., 2004; Reinhard et al., 2013; Planavsky et al., 2014; Sperling et al., 2015). In fact, Fe-S

62 systematics and $\delta^{34} \mathrm{~S}$ measurements throughout the Roper Group suggest inner and distal shelf

63 depositional environments were likely oxic, while basinal shales record prolonged periods of

64 euxinia (Shen et al., 2003). Trace metal concentrations from the same basinal shales corroborate

65 basinal anoxia with extended periods of euxinia, but overlying surface waters were likely at least

66 transiently oxic (Cox et al., 2016). The "bioinorganic bridge hypothesis” (Anbar and Knoll,

67 2002) links these micropaleontological and geochemical observations, as follows: 
- Biological $\mathrm{N}_{2}$ fixation and assimilation of nitrate are catalyzed by metalloenzymes that contain siderophile or chalcophile elements in their active sites (Godfrey and Glass, 2011). cyanobacterial phytoplankton commonly outcompete their eukaryotic counterparts where fixed

89 nitrogen is scarce, because (a) only prokaryotes can fix atmospheric $\mathrm{N}_{2}$ and (b) organisms with 
91 1998; Karl et al., 2001; Bouman et al., 2011; Fawcett et al., 2011). Also, in modern oceans, the

92 infiltration of phytoplankton biomass by larger cells occurs when total rates of primary

93 production increase and grazing comes to limit production by smaller cells (Poulin and Franks,

94 2010); thus, small cyanobacterial cells would be expected to dominate in off-shore, nutrient-

95 limited environments.

96 Stüeken (2013), however, examined only one sedimentary basin, which may not have

97 been typical of global oceans at that time. Here we report nitrogen abundance and isotopic data

98 from two additional basins of roughly equivalent age, the Bangemall ( 1.5 Ga) and Roper ( 1.5-

$99 \quad 1.4 \mathrm{Ga}$ ) basins of western and northern Australia, respectively. Although cross-basinal transects

100 are not available, stratigraphic profiles through multiple sedimentary sequences provide samples

101 of deep subtidal, shallow subtidal and peritidal facies, allowing offshore-onshore comparisons of

102 relative nitrogen availability and speciation. Thus, they can indicate whether a nitrate constraint

103 on eukaryotic evolution was just a local phenomenon, or more likely a global feature during the

104 Mesoproterozoic.

105

$106 \quad 1.1$ Precambrian nitrogen cycling

107 Nitrogen cycling has been predominantly controlled by the biosphere since the advent of

108 biological $\mathrm{N}_{2}$ fixation no later than 3.2 billion years ago (Stüeken et al., 2015), but it has also

109 been influenced by changes in atmospheric and oceanic redox states. For example, the

110 appearance of free $\mathrm{O}_{2}$ as early as $2.8 \mathrm{Ga}$ (reviewed by Farquhar et al., 2011) in microbial mats

111 and marine surface waters (Lalonde \& Konhauser 2015, Olson et al. 2013) probably spurred the

112 radiation of nitrifying bacteria (Godfrey and Falkowski, 2009) because locally enhanced crustal

113 weathering (Anbar et al., 2007; Wille et al., 2007; Reinhard et al., 2009; Czaja et al., 2010; 
114 Kendall et al., 2010; Stüeken et al., 2012; Gregory et al., 2015; Kurzweil et al., 2015) would

115 have led to a greater influx of trace metals such as $\mathrm{Fe}, \mathrm{Cu}$, and Mo. Higher $\mathrm{O}_{2}$ levels combined

116 with increasing micro-nutrient availability would have facilitated the oxidation of ammonium to

117 nitrite and nitrate (reviewed by Buick, 2007; Godfrey and Glass, 2011). Complementary

118 denitrifying bacteria would have been stimulated by the resulting supply of nitrate (Garvin et al.,

119 2009; Godfrey and Falkowski, 2009). The extent of these coupled oxic-suboxic processes can be

120 inferred from the sedimentary record, because they impart a distinct kinetic fractionation on the

121 nitrogen isotopes of organic matter compared to those imparted by strictly anaerobic nitrogen

122 cycling (Table 1).

123 Heavy $\delta^{15} \mathrm{~N}^{(\mathrm{a})}$ values, greater than those produced by biological $\mathrm{N}_{2}$ fixation alone and

124 thus interpreted to represent aerobic nitrogen cycling, are known from the late Archean and early

125 Paleoproterozoic before the Great Oxidation Event (Yamaguchi, 2002; Garvin et al., 2009;

126 Godfrey and Falkowski, 2009; Busigny et al., 2013), and from the later Paleoproterozoic (Kump

127 et al., 2011; Godfrey et al., 2013), i.e. during and shortly after the proposed $\mathrm{O}_{2}$ overshoot at

128 2.35-2.06 Ga (Bekker et al., 2004; Bekker and Holland, 2012; Planavsky et al., 2012; Hardisty et

129 al., 2014; Scott et al., 2014, Fig. 1). This suggests that surface waters at these times contained

130 enough dissolved oxygen to form significant amounts of nitrate, which was then partially

131 denitrified in the water column and assimilated into biomass. Moreover, isotopic profiles from

132 cross-basinal facies show no trends (Godfrey and Falkowski, 2009; Godfrey et al., 2013),

133 indicating that nitrate was available in the most productive zone of the water column in both on-

134 shore and offshore settings. Similar patterns are also evident across Neoproterozoic basins (Ader 135 et al., 2014).

(a) $\delta^{15} \mathrm{~N}=\left[\left({ }^{15} \mathrm{~N} /{ }^{14} \mathrm{~N}\right)_{\text {sample }} /\left({ }^{15} \mathrm{~N} /{ }^{14} \mathrm{~N}\right)_{\text {standard }}-1\right] \cdot 1000$, where the standard is atmospheric $\mathrm{N}_{2}$. 
137 any other time in Earth's history. It has been predicted that the expansion of euxinic waters after

1381.8 Ga (Canfield, 1998; Arnold et al., 2004) would have led to the scavenging of trace metals

139 such as Mo, Cu, and Fe from seawater into sediments by organic compounds or low-temperature

140 sulfide mineral phases (Saito et al., 2003; Reinhard et al., 2013), restricting their availability for

141 use as metal cofactors in aerobic nitrogen cycle reactions (Anbar and Knoll, 2002; Buick, 2007).

142 For example, Mo concentrations may have been as low as 1-10 nM compared to $105 \mathrm{nM}$ today

143 (Reinhard et al., 2013), which may have limited biological $\mathrm{N}_{2}$ fixation and nitrate assimilation

144 (Zerkle et al., 2006; Glass et al., 2012). This may in turn have delayed the radiation of

145 photosynthetic eukaryotes, which are most productive under a steady supply of nitrate and are

146 incapable of $\mathrm{N}_{2}$ fixation (Anbar and Knoll, 2002). Nitrate scarcity could have created a positive

147 feedback on trace metal scavenging because it may have spurred microbial sulfate reduction and

148 consequently the expansion of euxinic environments (Boyle et al., 2013). This would have

149 prolonged nitrate limitation until the extent of euxinia contracted (Sperling et al., 2015) possibly

150 through a Neoproterozoic expansion of oxic waters (Canfield et al., 1996; Ader et al., 2014;

151 Thomson et al., 2015). For these reasons, much of the Mesoproterozoic ocean may have been

152 unsuitable for eukaryotic life.

153 Consistent with this idea, the Mesoproterozoic Belt basin displays a distinct onshore-

154 offshore gradient in nitrogen isotopes (Stüeken, 2013). This trend was interpreted to represent a

155 trend in nitrogen speciation, where nitrate was only available in near-shore environments while

156 an anaerobic nitrogen cycle dominated by $\mathrm{N}_{2}$ fixation prevailed offshore. A decrease in

157 dissolved oxygen concentration and/or bioessential trace metals in offshore environments 
158 probably restricted nitrification to shallow waters (Stüeken, 2013). Any nitrate that was produced

159 offshore was likely consumed rapidly and quantitatively at the chemocline.

161 2. Location and Geological Setting

$162 \quad 2.1$ Bangemall Supergroup

163 The Bangemall Supergroup crops out over $~ 100,000 \mathrm{~km}^{2}$ in northwestern Australia (Fig.

164 2). Our samples predominantly come from three stratigraphic transects spread over $100 \mathrm{~km}$ along

165 the Pingandy Shelf which forms the northern limb of the broad synclinorium in which the

166 Supergroup is now exposed: from west to east Irregully Creek, Wandarry Creek and Fords

167 Creek. These spanned almost the entire $\sim 5 \mathrm{~km}$ section of the Edmund and Collier Groups, the

168 components of the Supergroup preserved in this region. They largely consist of terrigenous

169 mudrocks and sandstones with subordinate carbonates, cherts and conglomerates. Because of

170 their broad outcrop area and facies relationships, they have been interpreted as entirely (Edmund

171 Group) or dominantly (Collier Group) marine (Martin and Thorne, 2004). Though parts of the

172 Bangemall basin may have been restricted from the open ocean, the Pingandy Shelf, from where

173 the great majority of our samples come, was evidently a long-lived basement high with variable

174 paleo-current patterns (Martin et al., 2004; 2008) suggesting that it was not an isolated and

175 restricted sub-basin. On the Pingandy Shelf, deformation has been modest with only broad open

176 folding during the Mutherbukin Tectonic Event, the Edmundian Orogeny, and the Mulka

177 Tectonic Event (Zi et al., 2015). Several episodes of dolerite sill intrusion occurred during the

178 Mesoproterozoic, causing local contact metamorphism of siliceous dolomites to talc-tremolite-

179 calcite assemblages in aureoles about 100 meters across (Buick et al., 1995). Otherwise

180 metamorphism has been insignificant with kerogen color grading from orange-brown in the east 
181 to mid-brown in the west indicating a temperature gradient from $100-125^{\circ} \mathrm{C}$ to $\sim 150^{\circ} \mathrm{C}$ towards

182 the western closure of the synclinorium (Buick and Knoll, 1999).

The Bangemall rocks studied here range in age from between 1680-1610 Ma at the base

184 of the stratigraphic section (Zi et al., 2015) to slightly older than $1070 \mathrm{Ma}$ at the top (Martin,

185 2002; Wingate, 2002; Martin et al., 2008), though most samples come from the >1465 Ma

186 Edmund Group (Wingate, 2002). Their depositional environments ranged from a peritidal

187 carbonate platform in the Irregully Formation at the base through arenaceous siliciclastic shelf

188 sediments containing scattered stromatolitic bioherms in the overlying Gooragoora, Blue Billy,

189 Cheyne Springs, Kiangi Creek and Muntharra Formations, to off-shore delta-front and turbiditic

190 deposits of the Discovery, Devil Creek, and Ullawarra Formations (Martin and Thorne, 2004).

191 The peritidal facies are characterized by silicified dolostones interbedded with green shale and

192 cross-bedded sandstone, forming meter-thick transgressive cycles that pass upward from wavy

193 laminated microbialites with intraclast breccias and teepee structures through stratiform,

194 pseudocolumnar and muricate (linked conical) stromatolites to large bulbous stromatolites

195 (Buick et al., 1995; Buick and Knoll, 1999). The shallow subtidal facies comprises unsilicified

196 dolostone lenses among coarse-to-fine cross-bedded sandstones, siltstones and grey shales, with

197 conical, domical and columnar stromatolites often on a gigantic scale up to 10 meters high and 5

198 meters broad. The deeper subtidal sediments deposited offshore commence with black

199 kerogenous and sulfidic shale and chert but are dominated by siltstone and grey-green shale with

200 minor fine sandstone and nodular to laminated dololutite and calcilutite, with stromatolite

201 fragments only occurring in breccia lenses.

202 In terms of geobiological context, $\delta^{13} \mathrm{C}_{\text {carb }}$ values are remarkably invariant throughout the 203 section, averaging $-0.5 \%$ $\pm 1.3 \%$ (Buick et al., 1995). The only significant deviation from such 
204 values occurs in the contact metamorphic aureoles around dolerite sills, where $\delta^{13} \mathrm{C}_{\text {carb }}$ can go 205 down to $-8.4 \%$. However, as these rocks are bleached and kerogen-free, they were not analyzed

206 in the current study. As noted above, stromatolites are ubiquitous in the peritidal facies, abundant

207 and gigantic in the shallow subtidal facies but present only as breccia fragments in the deeper

208 offshore facies. Microfossils are often preserved in early diagenetic chert nodules within the

209 peritidal stromatolites, recording benthic mat communities of small filamentous and coccoid

210 prokaryotes (the Siphonophycus-Sphaerophycus-Eosynecchococcus-Myxococcoides-

211 Palaeopleurocapsa assemblage of Buick and Knoll, 1999). In the shallow subtidal facies, large

212 non-matting filaments and planktonic sphaeromorph acritarchs with thin walls and moderate

213 dimensions are preserved in grey shale (the Siphonophycus-Leiosphaeridia-

214 Pterospermopsimorpha-Satka assemblage of Buick and Knoll, 1999). In offshore kerogenous

215 cherts and shales, only very large chuarid acritarchs with thick multilamellate walls (the

216 Crassicorium assemblage) are preserved, their complex ultrastructure indicating that they were

217 eukaryotic (Buick and Knoll, 1999). Relevant to nitrogen isotopes, Palaeopleurocapsa in the

218 peritidal facies is morphologically similar to an extant genus of $\mathrm{N}_{2}$-fixing cyanobacteria.

219

220

\subsection{Roper Group}

221 Samples from the roughly coeval Roper Group from northern Australia were also

222 analyzed in this study. These rocks crop out over 145,000 $\mathrm{km}^{2}$ and have a maximum thickness of 223 about 5000 meters. Their age ranges from 1492+/-4 Ma determined by U-Pb in zircon dating for

224 the basal Mainoru Formation (Page et al., 2000) to Re-Os dates of 1361+/-31 Ma and 1417+/-29

225 Ma from the upper Velkerri Formation (Kendall et al., 2009) and a 1429+/-31 Ma Rb-Sr date

226 from the McMinn Formation at the top of the section (Kralik, 1982). The size of the basin, the 
227 abundance of glauconite and sulfide minerals, and sedimentary features indicative of strong tidal

228 influence have been interpreted as indicating open exchange with the global ocean (Jackson and

229 Raiswell, 1991). Sediments are predominantly siliciclastic, ranging from mudrock to sandstone,

230 that were deposited in six progradational cycles (Abbott and Sweet, 2000). High degrees of

231 pyritization, large fractionations in sulfur isotopes and relatively small molybdenum isotope

232 fractionations in black shales indicate that anoxia was pervasive; euxinia was at least transient in

233 deeper parts of the basin and was possibly common along continental margins globally at this

234 time (Jackson and Raiswell, 1991; Shen et al., 2003; Arnold et al., 2004; Johnston et al., 2008;

235 Kendall et al., 2009; Sperling et al., 2015; Cox et al., 2016). In many areas, the rocks are

236 essentially unmetamorphosed, having never been exposed to temperatures above the oil window

237 (Jackson et al., 1988).

The Roper Group is richly fossiliferous (Peat et al., 1978), with microfossil assemblages

239 displaying onshore to offshore trends of decreasing abundance and diminishing diversity (Javaux

240 et al., 2001). There are abundant acritarchs with ultrastructure and ornamentation indicative of

241 eukaryotic affinities (Javaux et al., 2004). In support of this conclusion, kerogen and "live” oil

242 from shales and fluid inclusions yield diverse sterane hydrocarbon biomarkers derived from

243 eukaryotes (Summons et al., 1988; Dutkiewicz et al., 2003; Dutkiewicz et al., 2004; Volk et al.,

244 2005; Siljeström et al., 2013; but see Flannery \& George, 2014 for a contradictory finding),

245 though most biomarkers are of prokaryotic origin. Sulfur isotope studies suggest that some of

246 these prokaryotes metabolized by sulfate reduction (Donnelly and Crick, 1988) and sulfur

247 disproportionation (Johnston et al., 2008).

248 We obtained samples capturing a range of facies from the tide-dominated inner shelf

249 platform, the storm-dominated outer shelf, and from the deep basin (Abbott and Sweet, 2000). 
250 The tide-dominated inner shelf platform comprises sandstones interbedded with mudstones and

251 ooidal ironstones from a coastal sand platform; medium-bedded fine to coarse quartz sandstones

252 with trough cross-stratification and ripple marks from a tide-dominated shoreline; and medium to

253 thickly bedded sandstones that are massive or have swaley/hummocky cross-stratification from a

254 sand-dominated shelf. The storm-dominated shelf consists of thinly interbedded sandstone,

255 mudstone, and siltstone with ripple cross-laminae and small scours, or interlaminated siltstone

256 and mudstone with minor very fine-grained sandstone. Basinal samples comprise interbedded

257 mudstones and siltstones The samples came from four drill cores: Golden Grove 1 (GG1),

258 Broughton 1(Br1), Urapunga 4 (U4), and Amoco 82/3 (A82/3). Samples from the Mainoru,

259 Crawford, and Hodgson Formations represent one of the six coarsening-upward progradational

260 cycles; samples from the Corcoran and Velkerri Formations are from two separate, overlying

261 cycles (Abbott and Sweet, 2000).

262

263 3. Analytical methods

264

265 3.1. Sample preparation for bulk rock analyses

266 Sample preparation followed the methods of Stüeken (2013). Samples were first crushed

267 into centimeter-sized chips using equipment that was thoroughly cleaned with methanol and $18 \Omega$

268 Milli-Q deionized water. These chips were then sequentially cleaned in an ultrasonic bath with

269 hexane, methanol and deionized water for 10 minutes each to remove modern organic

270 contaminants. The samples were then dried in a fume hood. Next, the chips were pulverized into

271 a fine powder using an aluminum oxide ceramic puck mill that was cleaned with deionized

272 water, methanol, and pre-combusted silica sand between samples. The powder was treated with 
$2730.6 \mathrm{M} \mathrm{HCl}$ in three iterations (one per day) to dissolve all the carbonate, and then rinsed with

274 deionized water in three more iterations to remove all of the acid. The samples were then left to

275 dry in an oven $\left(60^{\circ} \mathrm{C}\right)$ for two days. The carbonate content was determined gravimetrically as

276 the difference in mass between the untreated and the decarbonated powder aliquot.

277

278 3.2. Kerogen extraction for organic nitrogen

279

During early diagenesis, mineralization can liberate $\mathrm{NH}_{4}{ }^{+}$from organic compounds, and

280 pore-water $\mathrm{NH}_{4}{ }^{+}$can then be sorbed by clay minerals through substitution for potassium, due to

281 their similar ionic radii. There is still no consensus on whether bulk analyses (kerogen + silicate-

282 bound nitrogen) or kerogen isolate analyses better record the primary isotopic signals in

283 sedimentary rocks, but due to the low metamorphic grade of these samples (section 5.1.4), it

284 could be that bulk analyses better reflect primary processes, as kerogen seems to be more

285 susceptible to metasomatic alteration (reviewed in Stüeken et al., 2016). However, we further

286 extracted the kerogen from a subset of samples where enough powder was available to quantify

287 the relative proportions and isotopic compositions of organic-bound and silicate-bound nitrogen.

288 The protocol was adapted from Robl \& Davis (1993; see also Stüeken et al., 2015a). Around $5 \mathrm{~g}$

289 of rock powder were weighed into a $250 \mathrm{ml}$ Nalgene bottle and decarbonated with $100 \mathrm{ml}$ of $6 \mathrm{~N}$

$290 \mathrm{HCl}$ (reagent grade) at $60{ }^{\circ} \mathrm{C}$ in a shaking water bath overnight. Removal of $\mathrm{CaCO}_{3}$ reduces the

291 formation of insoluble calcium fluorides in subsequent steps. The acid was decanted after

292 centrifugation (45 min at $4000 \mathrm{rpm}$ ) and powders were washed once with DI- $\mathrm{H}_{2} \mathrm{O}(18 \mathrm{M} \Omega$ ).

293 Then the silicate matrix was dissolved with a mixture of $\mathrm{DI}-\mathrm{H}_{2} \mathrm{O}(100 \mathrm{ml})$ and concentrated $\mathrm{HF}$

294 (100 ml, reagent grade) at $60{ }^{\circ} \mathrm{C}$ in the shaking water bath overnight. The acid was again

295 decanted after centrifugation. Residual fluoride precipitates were removed by treating the sample 
296 with a mixture of $\mathrm{H}_{3} \mathrm{BO}_{3}\left(62.5\right.$ g, reagent grade), DI- $\mathrm{H}_{2} \mathrm{O}(100 \mathrm{ml})$ and concentrated $\mathrm{HF}$ (100

$297 \mathrm{ml}$ ) at room temperature in the shaking water bath overnight. After decanting the acid, the

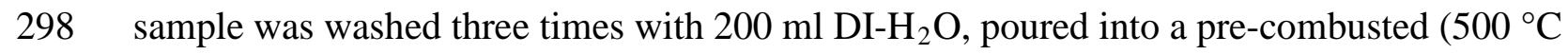

299 overnight) scintillation vial with $10 \mathrm{ml}$ of $\mathrm{DI}-\mathrm{H}_{2} \mathrm{O}$, and placed into a freeze-drier for two days to

300 remove excess water. Nalgene bottles were washed with soap, boiled in bleach for several hours,

301 refluxed with concentrated $\mathrm{HCl}$ and methanol overnight, thoroughly rinsed with $\mathrm{DI}-\mathrm{H}_{2} \mathrm{O}$, and

302 dried in a clean, closed oven between samples.

\section{$304 \quad 3.3$. Isotopic analyses}

305 Isotopic compositions $\left(\delta^{15} \mathrm{~N}_{\text {bulk }}, \delta^{15} \mathrm{~N}_{\mathrm{ker}}\right.$ and $\left.\delta^{13} \mathrm{C}_{\text {org }}\right)$ were determined using a Costech

306 ECS 4010 Elemental Analyzer coupled to a Thermo Finnigan 253 continuous flow isotope-ratio

307 mass spectrometer. Three in-house standards (two glutamic acids "GA1” and "GA2”, and dried

308 salmon "SA") calibrated with the international reference materials USGS40 and USGS41 (Qi et

309 al., 2003) were used to calibrate isotope measurements. Another in-house standard from the late

310 Archean Mt. McRae formation (UW McRae) was analyzed frequently as a test for long-term

311 precision (Stüeken et al., 2015a). Analytical blanks resulting from the combustion process were

312 monitored and subtracted for nitrogen isotope measurements; carbon backgrounds were

313 insignificant. The average analytical accuracy of $\delta^{15} \mathrm{~N}$ among the individual runs based on the

314 calibrated in-house standard "GA1" was $0.12 \pm 0.09 \%$ ( $1 \sigma)$. A similar test for accuracy

315 in $\delta^{13} \mathrm{C}_{\text {org }}$ measurements based on the calibrated in-house standard "SA" was $0.08 \pm 0.10 \%$ ( $\left.1 \sigma\right)$.

316 The average analytical precision of $\delta^{15} \mathrm{~N}$ and $\delta^{13} \mathrm{C}_{\text {org }}$ among the individual runs based on the in-

317 house standard "UW McRae” was 0.15\% ( $1 \sigma)$ and $0.13 \%$ ( $(1 \sigma)$ respectively. The average

318 standard deviation between individual sample replicates was $0.31 \%$ for $\delta^{15} \mathrm{~N}$ and $0.09 \%$ 
319 for $\delta^{13} \mathrm{C}_{\text {org }}$. Replication is the largest source of individual analytical uncertainty, and so it is used 320 to represent the error of individual sample analyses. Nearly all samples were analyzed at least

321 twice, except in cases where we were sample-limited. Samples where the $\delta^{15} \mathrm{~N}$ values varied by

322 more than $0.5 \%$ or that had a nitrogen sample/blank ratio of less than five were replicated further 323 to ensure no analytical biases.

325 4. Results

\section{4.1. Bangemall basin}

Bulk $\delta^{15} \mathrm{~N}$ values in the Bangemall basin have a maximum range from $-1 \%$ o to $+7.5 \%$

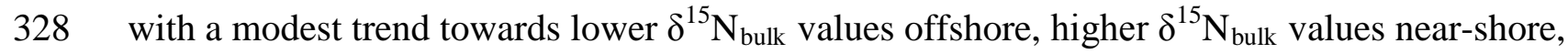

329 and variable $\delta^{15} \mathrm{~N}_{\text {bulk }}$ values in peritidal environments (Table A1). Each of the three stratigraphic

330 sections (Fords Creek, Irregully Creek, and Wandarry Creek; Fig. 3) shows these characteristics

331 (Table 2). Because the three sections cover equivalent facies, we normalized them with respect to

332 the thickness of the shallow subtidal facies described by Buick et al. (1995) and plotted a

333 composite sequence of $\delta^{15} \mathrm{~N}_{\text {bulk }}$ values from deep to peritidal environments shown in Fig. 3.

334 Using all analyses from this composite transect, plus a few additional samples from other

335 localities, the average $\delta^{15} \mathrm{~N}_{\text {bulk }}$ value is $+3.3 \%$ o $\pm 1.8 \%$ o $(\mathrm{n}=18)$ for the peritidal facies, $+3.4 \%$ o \pm

336 1.4\%o $(n=26)$ for the shallow subtidal facies, and $+1.8 \%$ o $\pm 1.6 \%$ o $(n=28)$ in the deep water facies.

337 Both the peritidal and shallow subtidal environments are statistically heavier than the basinal

338 environment ( $\mathrm{p}_{\text {one-tailed }}=0.003$ and 0.00008 respectively), though peritidal and shallow

339 subtidal $\delta^{15} \mathrm{~N}_{\text {bulk }}$ values are not statistically different from one another ( $\left.\mathrm{p}_{\text {one-tailed }}=0.67\right)$. The

340 isotopic composition of kerogen isolates match well with the measured $\delta^{15} \mathrm{~N}_{\text {bulk values (average }}$

341 difference of $0.8 \%$ among replicated samples) (Table A3), which indicates that the observed 
342 gradient is not an artifact of mixing between isotopically distinct nitrogen reservoirs $\left(\mathrm{N}_{\text {kerogen }}\right.$ and

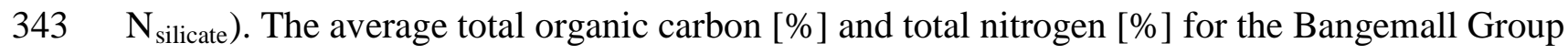

344 samples are $0.25 \%$, and $0.01 \%$ respectively (See table A1).

345 The same set of samples has $\delta^{13} \mathrm{C}_{\text {org }}$ values that mostly range from -25\%o to -35\%. We

346 found a slight basinal gradient of about 3\%o with lighter $\delta^{13} \mathrm{C}_{\text {org }}$ in samples deposited in deeper

347 subtidal environments (Table 3). Samples from each depositional environment come from

348 statistically different $\delta^{13} \mathrm{C}_{\text {org }}$ populations ( $\mathrm{p}_{\text {anova }}=0.002$ ).

\subsection{Roper basin}

The Roper basin has $\delta^{15} \mathrm{~N}_{\text {bulk }}$ values ranging from -1\%o to $+4.9 \%$ o with a facies-dependent

352 trend from lighter values in basinal and storm-dominated shelf samples to heavier values in tide-

353 dominated platform samples (average gradient in Tables 2, all data in A2). The mean $\delta^{15} \mathrm{~N}_{\text {bulk }}$

354 value in the tide-dominated platform environment is statistically different from that of the storm-

355 dominated shelf and basinal environments ( $\mathrm{p}_{\text {one-tailed }}=0.008$ and 0.0005 respectively). The outer

356 shelf and basinal $\delta^{15} \mathrm{~N}_{\text {bulk }}$ populations are statistically indistinguishable from one another ( $\mathrm{p}_{\text {one- }}$

357 tailed $=0.27)$. The average total organic carbon [\%] and total nitrogen [\%] for the Roper Group

358 samples is $0.34 \%$, and $0.02 \%$ respectively (See table A2).

359 Unlike the Bangemall Group, the Roper Group shows no sign of a trend in $\delta^{13} \mathrm{C}_{\text {org }}$ across

360 the basin (total average $-31.3 \%$ o $1.55 \%$, $n=34$, Table 3). Again, kerogen isolates are very

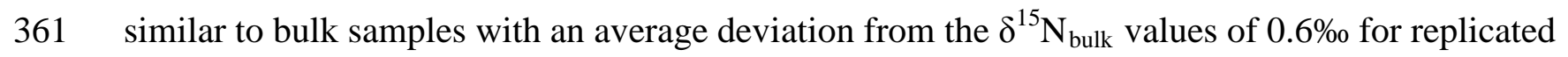
362 samples (Table A3). 


\subsection{Diagenesis and Metamorphism}

366 5.1.1. Oxic diagenesis: effects on preserved $\delta^{15} N_{\text {bulk }}$

367 Diagenesis under oxic conditions may increase $\delta^{15} \mathrm{~N}_{\text {bulk }}$ by as much as $+4 \%$ (Freudenthal 368 et al., 2001; Lehman et al., 2002) due to kinetic fractionation of nitrogen isotopes in favor of ${ }^{14} \mathrm{~N}$ 369 during the deamination of organic matter (Macko and Estep, 1984), followed by oxidation and 370 loss of the resulting light inorganic nitrogen (Freudenthal et al., 2001; Robinson et al., 2012). We 371 have no quantitative evidence to completely rule out any effect of oxic diagenesis; however it 372 could not by itself explain the full ranges of $\delta^{15} \mathrm{~N}_{\text {bulk }}$ values we observe in the Bangemall (8\%o) 373 and Roper (6\%) groups, which are greater than the maximum range known to be caused by 374 aerobic diagenesis. Furthermore, in the absence of bioturbation, middle Proterozoic sediments 375 should have been largely anoxic even under an oxic water column. Hence the effects would 376 likely have been much smaller than in modern sediment profiles (Freudenthal et al., 2001). In 377 thin sections from the Bangemall Group, shallow sediments show no evidence of being more 378 oxidized than deeper equivalents. In particular iron oxides, which have a lower redox potential 379 than nitrate and should thus have formed if pore fluids that were oxidizing enough for 380 nitrification, are absent in both facies. Therefore, a systematic bias of shallow oxic and deep 381 anoxic diagenetic isotope effects is unlikely to be the reason for the basinal gradients in $\delta^{15} \mathrm{~N}_{\text {bulk }}$.

\subsubsection{Anoxic diagenesis: effects on preserved $\delta^{15} N_{\text {bulk }}$}

Anoxic diagenesis can decrease the $\delta^{15} \mathrm{~N}_{\text {bulk }}$ of bulk nitrogen in sediments through either

385 the addition of ${ }^{15} \mathrm{~N}$-depleted biomass from in-situ growth of anaerobic bacteria (Lehman et al., 386 2002), or if organic compounds with relatively higher $\delta^{15} \mathrm{~N}$ values such as proteins (Macko et al., 387 1987) are preferentially degraded, releasing isotopically heavy $\mathrm{NH}_{4}{ }^{+}$into pore waters. However, 
neither of these mechanisms should have introduced a basinal gradient, because as noted above

389 all sediment samples in this study likely underwent anoxic diagenesis regardless of the redox

390 state of the overlying water column. Indeed if anoxic diagenesis caused addition of light $\mathrm{N}_{\text {org }}$

391 from bacterial growth, derived from $\mathrm{N}_{2}$ fixation or the preservation of its isotopic signal,

392 (Lehman et al., 2002), then preferential growth of those organisms in deeper environments

393 would only support our interpretation of offshore nitrate depletion (discussed below). We can

394 further address the latter mechanism, i.e. preferential ${ }^{15} \mathrm{~N}$ loss from degrading biomass, by

395 comparing bulk $\delta^{15} \mathrm{~N}$ values to the $\delta^{15} \mathrm{~N}$ values of kerogen isolates. This diagenetic pathway

396 should have led to an isotopic enrichment in silicate minerals that absorbed some of the

397 dissolved heavy $\mathrm{NH}_{4}{ }^{+}$. Hence the $\delta^{15} \mathrm{~N}$ of the kerogen isolate from a sample should be

398 systematically lighter than its bulk value, which is not observed. In fact, the Roper and

399 Bangemall kerogen analyses show a very slight average isotopic enrichment of $+0.6 \%$ and

$400+0.8 \%$, respectively, over the bulk analyses (Table A1). These data may be best explained if

$401 \mathrm{NH}_{4}{ }^{+}$release did not lead to a net isotopic fractionation, perhaps because the effects of kinetic

402 fractionation during deamination (Macko and Estep, 1984) and relative compound instabilities

403 (cf. Macko et al., 1987) were roughly balanced. Bulk sediment values are therefore probably

404 close to the original isotopic composition of biomass.

405

406 5.1.3. Diagenetic effects on the $\delta^{13} \mathrm{C}$ of organic matter

407 Both aerobic and anaerobic diagenesis mildly decrease the $\delta^{13} \mathrm{C}$ of organic matter to a 408 maximum of 1.6\%o (Freudenthal et al., 2001; Lehman et al., 2002), probably due to preferential

409 degradation of isotopically heavy organic compounds. Carbohydrates and proteins, which are

410 more susceptible to microbial degradation under both oxic and anoxic conditions, tend to be 
411 more enriched in $\delta^{13} \mathrm{C}$ than other more recalcitrant fractions such as lipids (Lehman et al., 2002).

412 Diagenetic effects can be larger (on the order of 20\%o depending on the substrate) if organic

413 degradation is catalyzed by microbes using the Wood-Ljungdahl pathway, which includes

414 methanogens, methanotrophs, and acetogens (Freude and Blaser, 2016). The range of $\delta^{13} \mathrm{C}_{\text {org }}$ in

415 the Bangemall samples is too large ( 10\%) to be explained solely by diagenetic effects that do

416 not involve the Wood-Ljungdahl pathway. The slight gradient from lighter values offshore to

417 heavier values near-shore is similar to the environmental trends seen in other studies spanning

418 the Archean and Proterozoic (Eigenbrode and Freeman, 2006; Bekker et al., 2008; Guo et al.,

419 2013), suggesting that it is a primary feature reflecting differential contributions from varying

420 microbial metabolisms in response to local redox conditions (Section 5.2).

421

422 5.1.4. Metamorphism

423 Four lines of evidence indicate that the effects of metamorphism on primary nitrogen

424 isotope signals were probably insignificant. First, as stated previously, both the Bangemall and

425 Roper rocks were not exposed to temperatures much above the oil window (Jackson et al., 1988;

426 Buick and Knoll, 1999), whereas there seems to be no metamorphic effects on nitrogen isotopes

427 (i.e. preferential loss of ${ }^{14} \mathrm{~N}$ ) in other rocks up through the gas window (Rivera et al., 2015);

428 these may only become important (> $1 \%$ o) at greenschist facies and above (reviewed by

429 Thomazo and Papineau, 2013). Second, the slight metamorphic gradient from east to west in the

430 Bangemall basin does not parallel, but is nearly perpendicular to, the three transects, but no

431 significant differences are evident between them. Third, if metamorphism did have an effect on

432 the nitrogen isotope ratios of the samples, then increasing $\delta^{15} \mathrm{~N}_{\text {kerogen }}$ should correlate with

433 increasing $(\mathrm{C} / \mathrm{N})_{\text {kerogen }}$ ratios, as nitrogen is more mobile than carbon and ${ }^{14} \mathrm{~N}$ is more mobile 
434 than ${ }^{15} \mathrm{~N}$ under such conditions (Haendel et al., 1986; Bebout and Fogel, 1992; Jia, 2006).

435 However, such correlations are not seen in either sample set (Fig. 4, $r^{2}=0.28$ for Bangemall, and $436 \mathrm{r}^{2}=0.14$ for Roper). Lastly, offsets between $\delta^{15} \mathrm{~N}_{\text {silicate }}$ and $\delta^{15} \mathrm{~N}_{\text {kerogen }}$ of up to $12 \%$ have been 437 observed in rocks within hornfels aureoles (Godfrey and Falkowski 2009), suggesting there may 438 be a relationship between increasing metamorphic grade and increasingly divergent $\delta^{15} \mathrm{~N}_{\text {bulk }}$ and $439 \delta^{15} \mathrm{~N}_{\text {kerogen }}$ values. There is little consensus on whether kerogen or bulk nitrogen better preserves 440 primary biological signals (see Stüeken et al., 2016); however, on average, the kerogen nitrogen 441 isotope values in the Bangemall and Roper Groups fall within 0.7\%o of bulk values, inconsistent 442 with significant metamorphic alteration.

443 In the case of carbon isotopes, metamorphism also can spur exchange between the carbon 444 in organic matter and the carbon in carbonates, causing $\delta^{13} \mathrm{C}_{\text {carb }}$ to become depleted by up to $5 \%$ 445 and $\delta^{13} \mathrm{C}_{\text {org }}$ to become enriched by as much as 15\%o (reviewed by Schidlowski, 1987). This 446 effect is sensitive to the relative percentages of carbonate to organic carbon. Hence in carbonate447 rich sediments such as the Bangemall samples, depletion of the carbonate may not be noticeable 448 but enrichment of organic matter might be prominent. However, fractionations caused by carbon 449 equilibration between organics and carbonates are generally insignificant below greenschist 450 facies (McKirdy and Powell, 1974; Hoefs and Frey, 1976; Hayes et al., 1983). There is no 451 inverse correlation between the $\delta^{13} \mathrm{C}_{\text {org }}$ and $\delta^{13} \mathrm{C}_{\text {carb }}$ values of the same Bangemall samples $\left(\mathrm{r}^{2}=\right.$ 452 0.003), and the total fractionation $\Delta^{13} \mathrm{C}\left(=\delta^{13} \mathrm{C}_{\text {carb }}-\delta^{13} \mathrm{C}_{\mathrm{org}}\right)$ is not inversely correlated with 453 carbonate content $\left(r^{2}=0.008\right)$, even in the largest negative excursions of $\delta^{13} \mathrm{C}_{\text {carb }}$. These lines of 454 evidence all suggest the carbon isotopic composition of the samples measured in this study are 455 unaltered by metamorphism. 


\subsection{Carbon cycling in the Bangemall and Roper basins}

458

459

460

461

462

463

464

465

466

467

468

469

470

471 (Eigenbrode and Freeman, 2006; Bekker et al., 2008; Guo et al., 2013). All $\delta^{13} \mathrm{C}_{\text {org }}$ values in the

472 Bangemall and Roper basins are consistent with autotrophic fixation of $\mathrm{CO}_{2}$ by the Calvin cycle

473 that is used by a wide range of organisms including cyanobacteria and eukaryotic algae (Hayes,

474 2001). However, the fact that multiple basins through time show a similar trend suggests there

475

476

477

478

479

depleted values offshore and more enriched values near-shore (Table 3). The $\delta^{13} \mathrm{C}_{\text {org }}$ gradient in

the Bangemall basin is thus the opposite to that of the Belt basin (Stüeken, 2013), where onshore sediments are markedly depleted in $\delta^{13} \mathrm{C}$ compared to offshore sediments (Table $3, \mathrm{p}_{\text {anova }}=$ 0.0009). However, a similarly oriented gradient to this study was recently reported from the roughly contemporaneous Jixian Group (1.5 Ga) with values around -28.2\%o onshore and 30.8\%o offshore with $\mathrm{p}_{\text {anova }}<0.0001$ (Table 3, Guo et al., 2013). Given that $\delta^{13} \mathrm{C}_{\text {carb }}$ is nearly invariable in this and earlier Mesoproterozoic basins (Buick et al., 1995), this gradient is probably not caused by changes in the isotopic composition of dissolved inorganic carbon, as seen from the later Mesoproterozoic onwards (Bartley and Kah, 2004; Gilleaudeau and Kah, 2013), but may instead reflect spatial variability in biological fractionation effects. A similar trend was also observed in the Pretoria and Fortescue Groups, which along with the Jixian Group and Bangemall Group represent the Mesoproterozoic, Paleoproterozoic, and Neoarchean.

may be (i) autotrophic carbon fixation under a gradient of nutrient availability, or (ii)

photoautotrophic biomass mixed with varying proportions of secondary chemoautotrophic and/or heterotrophic biomass, as proposed for the contemporaneous Belt and Jixian basins (Guo et al., 2013; Stüeken, 2013). Such secondary metabolisms could include methanogenesis, acetogenesis, and methanotrophy that use the Wood-Ljungdahl pathway and are known to cause large 
480 fractionations in carbon isotopes (Freude and Blaser, 2016) We cannot rule out either

481 possibility, and it is also not clear why the reverse gradient is seen in the Mesoproterozoic Belt

482 basin (Stüeken, 2013). The samples from the Roper Group do not show a gradient in $\delta^{13} \mathrm{C}_{\text {org }}$ 483 values.

\subsection{Nitrogen cycling in the Bangemall and Roper basins}

The Bangemall transects and the Roper Group samples all show a 1.0\%o to 2.0\%o gradient in nitrogen isotopes, with lighter values recorded in offshore facies and heavier values in near-shore facies. We note that our results for the deep subtidal/basinal facies of the Bangemall and Roper groups $(+1.8 \%$ $\pm 1.6 \%, \mathrm{n}=28 ;+2.0 \% \mathrm{o} \pm 0.8 \%, \mathrm{n}=8$ respectively) are in

490 good agreement with basinal mudstones from the roughly contemporaneous Xiamaling

491 Formation $\left(\delta^{15} \mathrm{~N}_{\text {bulk }}=+2.1 \pm 0.2 \%\right.$ o, $\mathrm{n}=4$, age $1.37 \mathrm{Ga}$ ) (Luo et al., 2015). The facies-dependent

492 trend in the Bangemall and Roper basins likely reflects primary nitrogen cycling rather than post493 depositional alteration (see above), and so is interpreted as being consistent with cross-basin 494 differences in nitrogen speciation, comparable to the Belt basin (Table 2; Stüeken, 2013). As 495 noted in Section 1, Fe-S systematics, $\delta^{34}$ S, and trace metal data also have facies-dependent trends 496 in the Roper Group, providing evidence for an oxic near-shore water column, and anoxic/euxinic 497 basinal deep waters overlain by at least transiently oxic surface waters (Shen et al., 2003; Cox et 498 al., 2016). There are no equivalent data for the Bangemall Group, but a similar range of 499 conditions appears to have been widespread in the Mesoproterozoic ocean (Sperling et al., 2015).

500 These data are consistent with, and indeed support, our interpretation of the nitrogen isotope data 501 which follows. 
The lightest $\delta^{15} \mathrm{~N}_{\text {bulk }}$ values are most plausibly explained by an ecosystem dominated by

$503 \mathrm{~N}_{2}$ fixation using the molybdenum-bearing nitrogenase Nif (Zerkle et al., 2008; Nishizawa et al.,

504 2014; Zhang et al., 2014). If the ocean had been fully oxygenated at that time, more so than

505 today, then values around $0 \%$ could in theory also have been produced by quantitative

506 nitrification of biomass followed by quantitative re-assimilation of nitrate without any

507 denitrification and consequent isotopic fractionation in oxygen-minimum zones (Quan and

508 Falkowski, 2009). However, this scenario is unlikely in the mid-Proterozoic, where widespread

509 anoxia has been well documented (Arnold et al., 2004; Planavsky et al., 2011; Poulton and

510 Canfield, 2011; Reinhard et al., 2013; Sperling et al., 2015). An $\mathrm{N}_{2}$-fixation dominated regime is

511 thus the most parsimonious explanation for light $\delta^{15} \mathrm{~N}_{\text {bulk }}$ values in our samples.

512 Three alternative mechanisms can be considered to explain the isotopically heavy $\delta^{15} \mathrm{~N}$

513 values (> 2\%o) (see Stüeken, 2013, Ader et al., 2016, and Stüeken et al., 2016 for detailed

514 discussion).

515 (i) It has been hypothesized that in an anaerobic nitrogen cycle, partial assimilation of an

$516 \quad \mathrm{NH}_{4}{ }^{+}$pool by organisms can leave the residual $\mathrm{NH}_{4}{ }^{+}$pool enriched in ${ }^{15} \mathrm{~N}$, as life

517 preferentially assimilates ${ }^{14} \mathrm{~N}$ into biomass (Papineau et al., 2009). If this enriched pool of

$518 \mathrm{NH}_{4}{ }^{+}$is subsequently transported to a different location and assimilated by organisms,

519 two isotopic facies result: the first location preserves light $\delta^{15} \mathrm{~N}_{\text {bulk }}$ and the second

$520 \quad$ preserves heavy $\delta^{15} \mathrm{~N}_{\text {bulk }}$.

521 (ii) Partial nitrification of $\mathrm{NH}_{4}{ }^{+}$can create a nitrate pool that is depleted in ${ }^{15} \mathrm{~N}$ and a

522 residual $\mathrm{NH}_{4}{ }^{+}$pool that is enriched in ${ }^{15} \mathrm{~N}$ because nitrification preferentially selects for

523 the lighter isotope. Assimilation of the $\mathrm{NH}_{4}{ }^{+}$pool will result in heavy $\delta^{15} \mathrm{~N}_{\text {bulk }}$ so long as

524 the light nitrate is removed from the system, either through subsequent complete 
denitrification or relocation. Partial nitrification is rare in modern water columns,

526

527

528

529

530

531

532

533

534

535

536

537

538

occurring where seasonally fluctuating oxygen concentrations occur in transiently

stratified waters (Granger et al., 2011; Morales et al., 2014). However, it is possible that

low oxygen concentrations in the Mesoproterozoic enabled more widespread partial

nitrification coupled with the removal of the light nitrate pool by complete denitrification.

Subsequent uptake of the leftover heavy $\mathrm{NH}_{4}{ }^{+}$and further remineralization of organic

matter to $\mathrm{NH}_{4}{ }^{+}$could result in a range of positive $\delta^{15} \mathrm{~N}_{\text {bulk }}$ values (Stüeken, 2013;

Morales et al., 2014).

(iii) Partial denitrification of a nitrate pool in the water column will leave the residual nitrate enriched in ${ }^{15} \mathrm{~N}$, as the biologically governed steps of denitrification, like nitrification, preferentially use ${ }^{14} \mathrm{~N}$ over ${ }^{15} \mathrm{~N}$. So $\mathrm{N}_{2(\mathrm{~g})}$, the most common end-product of denitrification, would be isotopically depleted in ${ }^{15} \mathrm{~N}$ and organisms could assimilate the remaining heavy nitrate pool. This is the mechanism producing heavy $\delta^{15} \mathrm{~N}_{\text {bulk }}$ in the modern ocean (e.g. Sigman et al., 2009b; Tesdal et al., 2013).

Mechanisms (i) and (ii) should result in two distinct isotopic reservoirs, one that is relatively depleted below $-2 \%$, and one that is relatively enriched above $+1 \%$. There are no samples or sample sets from this study that are lighter than the $\delta^{15} \mathrm{~N}_{\text {bulk }}$ values that would result from $\mathrm{N}_{2}$ fixation by Mo-nitrogenase (-2\%o to $+1 \%$, Zhang et al., 2014). We cannot rule out that a much lighter facies exists somewhere within or adjacent to the Bangemall and Roper basins, but was not sampled. Nevertheless, explanations (i) and (ii) are unlikely for several reasons. First, the Black Sea, our best modern analog for the Mesoproterozoic ocean, has a large $\mathrm{NH}_{4}{ }^{+}$ reservoir in the anoxic bottom water, but underlying sediments do not record evidence of partial $\mathrm{NH}_{4}{ }^{+}$assimilation; values are close to $0 \%$, reflecting nitrogen limitation and $\mathrm{N}_{2}$ fixation in the 
548 photic zone (Fulton et al., 2012). The same is true for the modern anoxic Cariaco basin (Haug et 549 al. 1993). This argues against an isotopically light nitrogen reservoir resulting from partial $\mathrm{NH}_{4}{ }^{+}$ 550 assimilation in the similarly chemically stratified Mesoproterozoic ocean (option i).

551 Hydrodynamically, the Black Sea and Cariaco basin are probably more stagnant than open 552 marine settings like the Roper and Bangemall basins, and so it is conceivable that these 553 Mesoproterozoic settings experienced a relatively higher upwelling flux of $\mathrm{NH}_{4}{ }^{+}$from deeper 554 waters into the photic zone. In theory, this scenario could favor non-quantitative $\mathrm{NH}_{4}{ }^{+}$ 555 assimilation. However, in the modern ocean, $\mathrm{NO}_{3}{ }^{-}$assimilation usually goes to completion with 556 small net isotopic fractionations because nitrogen is often a limiting nutrient (e.g. Tesdal et al. 557 2013, Thunnel et al. 2004). There is no a priori reason to expect that this would have been 558 different if the nitrogen compound was $\mathrm{NH}_{4}{ }^{+}$instead of $\mathrm{NO}_{3}{ }^{-}$. This is especially true if low Mo 559 levels reduced $\mathrm{N}_{2}$ fixation rates in the Mesoproterozoic ocean and exacerbated nitrogen 560 limitation (Reinhard et al. 2013). Furthermore, upwelling would have been most pronounced 561 along the continental margin rather than far offshore, and so the hypothetical isotopically light 562 reservoir should be preserved in our sample set, which is not the case. Regarding option (ii), in 563 the Black Sea nitrification quickly goes to completion under suboxic conditions at the 564 chemocline (Fuchsman and Murray, 2008). The same is true in bacterial cultures and oxygen 565 minimum zones along open marine margins (Füssel et al., 2012; Martens-Habbena et al., 2009; 566 Thamdrup et al., 2012), suggesting that partial nitrification may also have been rare in the past as 567 long as surface waters were at least mildly oxidizing. Indeed, in modern environments partial 568 nitrification requires transient seasonal changes in the environment such as fluctuating sea ice 569 cover and is not known to operate over long geologic timescales. This leaves option (iii), partial 570 denitrification at the chemocline (cf. Sigman et al., 2009b) or in sediment pore waters (Kessler et 
571 al., 2014) as the most plausible mechanism responsible for heavier $\delta^{15} \mathrm{~N}_{\text {bulk }}$ values in the

572 shallower facies of the Bangemall and Roper basins. We thus interpret the large variations of

$573 \delta^{15} \mathrm{~N}_{\text {bulk }}$ in the Bangemall and Roper basins as reflecting differential mixing between components

574 derived from $\mathrm{N}_{2}$ fixation (alone responsible for the most depleted values between $-2 \%$ o to $+1 \%$ )

575 and from an aerobic nitrogen cycle coupled with varying degrees of partial denitrification of a

576 nitrate pool followed by nitrate assimilation yielding $\delta^{15} \mathrm{~N}_{\text {bulk }}$ values above $+1 \%$.

577 As some peritidal samples have anomalously light $\delta^{15} \mathrm{~N}_{\text {bulk }}$ values, it may be that $\mathrm{N}_{2}$

578 fixation temporarily dominated in microbial mats that were transiently cut off from the marine

579 nitrate pool at low tide, which would be consistent with microfossil evidence from the

580 Bangemall basin peritidal facies, where Palaeopleurocapsa (morphologically similar to a

581 modern genus of nitrogen-fixing cyanobacteria; Section 2.1) is found (Buick and Knoll, 1999).

582 All shallow subtidal samples have $\delta^{15} \mathrm{~N}_{\text {bulk }}$ values above $+1 \%$ (barring one outlier), suggesting

583 that some nitrate was always available in the water column and that there was a permanent

584 chemocline where partial denitrification was occurring. Deep subtidal samples have

585 lower $\delta^{15} \mathrm{~N}_{\text {bulk }}$ values than shallow (Table 2) and contain samples within the $-2 \%$ to $+1 \%$ range

586 (Fig. 5, 6). Almost all deep-water values for both basins are lighter than $+3 \%$, i.e. lighter than

587 most modern and recent marine sediments (>+4 \%, e.g. Sigman et al., 2000; Galbraith et al.,

588 2013; Algeo et al., 2014). This suggests that offshore sites had less nitrate available compared to

589 shallower facies and the modern deep ocean. Thus our data is consistent with at least some

590 nitrate in all depositional environments in both the Bangemall and Roper basins, but relatively

591 more in near-shore facies than offshore. When we discuss nitrate availability, we refer to

592 availability in the zones of highest biological production, as this zone will result in the

593 dominating isotopic signal preserved in sediments. This is probably the photic zone, and it is 
594 unlikely that nitrate could have existed much deeper in the water column if bottom waters during 595 the Mesoproterozoic were predominantly anoxic.

\section{4. $\delta^{15} \mathrm{~N}_{\text {bulk }}$ variability in the Bangemall and Roper basins}

The variability of $\delta^{15} \mathrm{~N}_{\text {bulk }}$ values in the Bangemall and Roper shallow water facies can be better understood by drawing an analogy to the variability of $\delta^{34} S$ values proposed for the Proterozoic (Kah et al., 2004). In this conceptual model, the rate of change in the nitrate isotopic composition in the shallow water environments is controlled by the size of the nitrate reservoir, and the size and isotopic composition of fluxes that both add and remove isotopically distinct nitrogen. The relationship is as follows, with fluxes labeled in Figure 7:

$610 \delta^{15} \mathrm{~N}_{\mathrm{NO} 3}$-, which is the isotopic difference of the ammonium being upwelled and the existing

611 shallow water nitrate reservoir. $\mathrm{F}_{\text {nitri. }} * \Delta_{\text {nitri. }}$ is the isotopic flux term of organic nitrogen that is

612 nitrified within the shallow water environment. $\Delta_{\text {nitri. }}$ is 0 because nitrification likely goes to

613 completion, and will preserve the isotopic composition of shallow water nitrate, from which the

614 organic matter was likely derived. $\mathrm{F}_{\text {fixation }} * \Delta_{\text {fixation }}$ is the isotopic flux contributed by $\mathrm{N}_{2}$ fixation

615 in shallow water environments. This flux could contribute to changes in the isotopic composition

616 of shallow water nitrate as $\Delta_{\text {fixation }}$ equals $\delta^{15} \mathrm{~N}_{\text {fixation }}-\delta^{15} \mathrm{~N}_{\mathrm{NO} \text {-3. }}$ It may be the case, however, that

$617 \quad \mathrm{~F}_{\text {fixation }}$ is 0 because $\mathrm{N}_{2}$ fixation was probably negligible onshore where nitrogen was more

618 available. $\mathrm{F}_{\text {assim }} * \Delta_{\text {assim }}$ is the isotopic flux of nitrogen being assimilated by shallow water 
619 organisms. This is likely also 0, as there is no evidence for non-quantitative assimilation

620 (negative $\delta^{15} \mathrm{~N}_{\text {bulk }}$ values). $\mathrm{F}_{\text {den.sed. }}{ }^{*} \Delta_{\text {den.sed }}$ is the isotopic flux associated with sedimentary

621 denitrification. $\Delta_{\text {den.sed }}$ is also close to 0 , as sedimentary denitrification does not impart large

622 isotopic fractionations on the nitrate in the overlying water column (Kessler et al., 2014; Rooze

623 and Meilie, 2016). $\mathrm{F}_{\text {den.wc. }}{ }^{*} \Delta_{\text {den.wc }}$ is the isotopic flux from canonical water column

624 denitrification. $\Delta_{\text {den.wc }}$ is around $20 . \mathrm{M}_{\mathrm{NO3}-}$ is the total onshore nitrate reservoir in grams or

625 moles. Removing the 0 terms, we are left with:

626

627

$$
\mathrm{d}\left(\delta_{\mathrm{NO3}-}\right) / \mathrm{dt}=\left(\mathrm{F}_{\text {upwell }} * \Delta_{\text {upwell }}-\mathrm{F}_{\text {den.wc. }}{ }^{*} \Delta_{\text {den.wc. }}\right) / \mathrm{M}_{\mathrm{NO}-}
$$

The average isotopic rate of change is $14.7 \%$, $4.7 \%$, and $0.3 \%$ per 100 meters within the

628 shallow water facies of the Bangemall, Roper, and Belt basins respectively. The sedimentation

629 rates between the basins were likely different, but if we assume that they were somewhat

630 comparable then these isotopic rates of change may reflect primary changes in shallow water

631 nitrate. For the Belt basin $\mathrm{d}\left(\delta_{\mathrm{NO}-}\right) / \mathrm{dt}$ is an order of magnitude less than in the Bangemall and

632 Roper basins. In the context of our model, this would have to result from the Belt basin either

633 having a greater nitrate reservoir in shallow waters $\left(\mathrm{M}_{\mathrm{NO}-}\right)$, or smaller fluxes $\left(\mathrm{F}_{\text {upwell }} * \Delta_{\text {upwell }}\right.$ and

$\left.634 \mathrm{~F}_{\text {den.wc. }}{ }^{*} \Delta_{\text {den.wc }}\right)$. It is unlikely that the Belt basin had a greater nitrate reservoir compared to the

635 Bangemall and Roper basins because it was likely more restricted from the open ocean (see

636 following section). As a result of this restriction, upwelling and water column denitrification

637 fluxes were likely smaller in magnitude in the Belt basin than those in the Bangemall and Roper

638 basins.

639 In this conceptual model, then, the Bangemall and Roper basins, having a greater

640 connection to the open ocean, had larger upwelling and denitrification fluxes that, when altered,

641 resulted in changes in the isotopic composition of the shallow nitrate reservoir. This variability is 
642 reflected in the variability of $\delta^{15} \mathrm{~N}_{\text {bulk }}$ values from the shallow water depositional environments in

643 each basin. Variability in the deep basin can be attributed to a small nitrogen reservoir, where

644 incursions of nitrate into the deep ocean could not fully be isotopically buffered by existing

$645 \mathrm{NH}_{4}^{+}$. If the fixed nitrogen reservoir had been larger in the Mesoproterozoic ocean, then it would

646 have been less susceptible to isotopic change. The degree of variability in our sample sets may

647 thus be a reflection of a small and isotopically variable nitrogen supply in comparison to the

648 Paleo- and Neoproterozoic settings that are more uniform (Section 5.6).

652 5.5. Comparing the Bangemall and Roper basins to the Belt basin

The Bangemall and Roper basins show facies-dependent trends in nitrogen isotopes

654 similar in direction to but smaller in magnitude than the Mesoproterozoic Belt Supergroup

655 (Table 2; Stüeken, 2013), suggesting that such a pattern may have been common in the

656 Mesoproterozoic Era. The Belt basin, however, has a deep depositional environment where 80\%

$657 \quad(n=21)$ of the samples fall within the range of Nif $\mathrm{N}_{2}$ fixation, compared to $36 \%$ and $8 \%$ in the

658 Bangemall and Roper respectively. This difference could be an artifact of sampling, if relatively

659 deeper facies were sampled in the Belt and not captured in the Bangemall transects and Roper

660 samples. However, the Belt basin could instead have been more restricted and consequently

661 more strongly stratified than the Bangemall and Roper basins, which may have led more rapid

662 depletion of the dissolved nitrate reservoir. This hypothesis is supported by the geometry of the

663 Belt basin, which is thought to have been formed by intracontinental rifting (Lydon, 2007) and

664 may only have had limited exchange with the open ocean for some of its history (e.g. Winston, 
665 1990; Luepke and Lyons, 2001; Pratt, 2001). The unusually steep gradient in organic carbon

666 isotopes from -32.2\%o to -22.9\%o, which is not seen in any other Mesoproterozoic basins (Guo et

667 al., 2013, this study), further supports significant water mass stratification in the Belt basin.

668 Hence the subtler carbon and nitrogen isotopic gradients in the Roper and Bangemall basins may

669 be more representative of global marine conditions. Importantly, none of the three basins show

670 nitrogen isotope values within the range of vanadium or iron-based nitrogenases (<-6\%, Zhang

671 et al., 2014), suggesting that Mo was available in sufficient quantities for the dominance of the

672 molybdenum nitrogenase despite being present at low concentrations in the Mesoproterozoic

673 ocean (Reinhard et al., 2013).

674

675 5.6. Mesoproterozoic nitrate minimum

676 While available data are consistent with a basinal gradient in $\delta^{15} \mathrm{~N}_{\text {bulk }}$ and thus in nitrogen

677 speciation in the Mesoproterozoic (Section 5.3), this was not the case in the earlier and later

678 Precambrian. In the mid-Archean Witwatersrand Supergroup (2.87-2.96 Ga), sediments

679 deposited near estuaries (+1.2 $\pm 1.0 \%$ ) are on average slightly heavier than marine sediments

680 further offshore (-1.6 $\pm 0.8 \%$ ) (Stüeken et al., 2015a), but almost all of these values fall within

681 the range of biological $\mathrm{N}_{2}$ fixation. The subtle gradient is thus more likely a result of varying

$682 \mathrm{Fe}^{2+}$ availability to diazotrophic microbes (Zerkle et al., 2008) rather than a gradient in nitrate

683 abundance. Nitrate was likely scarce in all parts of the mid-Archean ocean, including shallow

684 waters (Stüeken et al., 2015a), consistent with very low levels of atmospheric oxygen at this time

685 (Pavlov and Kasting, 2002; Kurzweil et al., 2013; Lyons et al., 2014). Surface water nitrate

686 levels may have increased in the late Archean with the onset of low levels of oxidative

687 weathering and enhanced oxygenation of the surface ocean (Siebert et al., 2005; Wille et al., 
688

689

690

691

692

693

694

695

696

697

698

699

700

701

702

703

704

705

706

707

708

709

710

2007; Kendall et al., 2010; Stüeken et al., 2012; Zerkle et al., 2012; Gregory et al., 2015;

Kurzweil et al., 2015). In the Ghaap Group in South Africa (2.67-2.52 Ga), bulk $\delta^{15} \mathrm{~N}_{\text {bulk }}$ values

have a mean of $+4.6 \pm 2.0 \%$ and show no systematic variation between different facies, which

include shallow-water microbialites and deeper-water siliciclastic sediments (Godfrey and

Falkowski, 2009). These results were interpreted as evidence of aerobic nitrogen cycling

(Godfrey and Falkowski, 2009), implying that nitrate had become a significant ion in the surface

ocean at this time. Across the Archean-Proterozoic boundary in the Hamersley Group in Western

Australia (2.50-2.46 Ga), combined data sets from Garvin et al. (2009) and Busigny et al. (2013)

capture offshore marine facies from the outer shelf and the shelf edge, respectively, and in both

settings values are mostly above $+4 \%$, especially after the 'whiff of oxygen' at 2.5 Ga (Anbar et

al., 2007; Garvin et al., 2009; Stüeken et al., 2015b). Although data from contemporaneous

shallow marine sediments are not available, these fairly heavy values in offshore sediments are

distinct from the comparatively light values found in the Mesoproterozoic (Stüeken, 2013, this

study) and provide strong evidence for a significant reservoir of nitrate throughout the surface

ocean at the end of the Archean and extending into the early Paleoproterozoic. From the late

Paleoproterozoic, Godfrey et al. (2013) analyzed drill-core samples along a basinal profile in the Animikie Group (1.87-1.84 Ga) and reported a subtle gradient of 1.0-1.4\%o from onshore to offshore, the latter being slightly lighter, but nearly all their values (98\%) were above +3\%o irrespective of environment. Hence nitrate was probably relatively abundant in the surface ocean across all environments in the Animikie basin. This may also have been the case in most of the Neoproterozoic where bulk $\delta^{15} \mathrm{~N}$ values are mostly above +2 \%o and show no systematic basinal gradient (Ader et al., 2014). From the late Neoproterozoic onwards, nitrate depletion is only reported during temporary anoxic events (e.g. Rau et al., 1987; Sephton et al., 2002; Ohkouchi et 
711 al., 2006; Junium and Arthur, 2007; LaPorte et al., 2009; Schoepfer et al., 2012; Wang et al.,

712 2013; Cremonese et al., 2014); throughout most of the Phanerozoic the nitrogen cycle seems to

713 have been predominantly aerobic with little spatial variance (Algeo et al., 2014). Hence the

714 Mesoproterozoic basins analyzed in this study appear to be anomalous in displaying subtle but

715 significant facies-dependent variation in nitrogen isotopes and, by inference, nitrogen speciation.

716 We cannot rule out the possibility that this pattern is biased by latitudinal or

717 oceanographic effects, because all of the Mesoproterozoic sites were originally located at low

718 latitudes ( $<30^{\circ}$, Idnurm et al., 1995; Elston et al., 2002) and in epicontinental seas, which could

719 have enhanced stagnation and stratification of the water column. The Paleoproterozoic Animikie

720 basin, on the other hand, formed at a higher latitude ( $>60^{\circ}$, Symons, 1966) possibly under colder

721 temperatures, which would have favored downward mixing of oxidants produced in the upper

722 ocean. Samples from other localities and better constraints on paleolatitude for other

723 Precambrian basins would be needed to test this possibility.

724 The relatively light $\delta^{15} \mathrm{~N}_{\text {bulk }}$ values in offshore sediments from the Mesoproterozoic are

725 unique and may have been a global characteristic of this time period (Fig. 6). Fig. 1 shows a

726 compilation of bulk nitrogen isotopic compositions from offshore marine environments,

727 highlighting the decline between $\sim 1.7 \mathrm{Ga}$ and $\sim 1.2 \mathrm{Ga}$ or possibly later. This interval

728 immediately post-dates the proposed mid-Paleoproterozoic oxygen overshoot $(\sim 2.3-2.0 \mathrm{Ga}$,

729 Bekker and Holland, 2012; Canfield et al., 2013; Partin et al., 2013; Hardisty et al., 2014) and

730 has recently been identified as a time when atmospheric $\mathrm{pO}_{2}$ may have dropped back to as little

731 as $0.1 \%$ or as great as 4\% (Zhang et al., 2016; Cox et al., 2016) of present atmospheric levels

732 until a second, potentially protracted rise to nearer modern amounts across the

733 Neoproterozoic/Paleozoic, possibly beginning at 800 Ma (Planavsky et al., 2014; Blamey et al., 
734 2016). Statistical analysis of global Fe-speciation data indicates that while subsurface anoxia was

735 widespread throughout the Proterozoic Eon, euxinia was disproportionately common in

736 Mesoproterozoic oceans (Sperling et al., 2015), consistent with lower atmospheric oxygen

737 levels. Marine sulfate concentrations are also thought to have declined after $1.7 \mathrm{Ga}$ from 10

$738 \mathrm{mM}$ to less than $1.8 \mathrm{mM}$, followed by a return to > 2-3 mM after 1.3 Ga (Kah et al., 2004;

739 Planavsky et al., 2012; Luo et al., 2014; Scott et al., 2014). Given that the redox potential of

740 nitrate is intermediate between that of sulfate and oxygen (Brookins, 1988), it is plausible that

741 the abundance of nitrate in the surface ocean also declined in the mid-Proterozoic. This would

742 have encouraged microbial $\mathrm{N}_{2}$ fixation, leading to relatively low $\delta^{15} \mathrm{~N}_{\text {bulk }}$ values in offshore

743 marine sediments (Fig. 6). Nitrification of ammonium to nitrate requires oxygen, and so the

744 production of nitrate was perhaps favored in shallow waters where $\mathrm{O}_{2}$ was actively being

745 produced. In contrast, nitrification may have been suppressed further offshore where $\mathrm{O}_{2}$

746 production was lower.

\subsection{Implications for life}

Both the Bangemall and the Roper basins have fossil assemblages that are consistent with

750 an onshore-offshore trend of decreasing organismic diversity and abundance seawards (Buick

751 and Knoll, 1999; Javaux et al., 2001). Stüeken (2013) suggested there could be a linkage

752 between the basinal nitrate gradient observed in the Belt basin and the fossil distributions in the

753 Bangemall and Roper basins, if they also had a nitrate gradient. Although our data are

754 inconsistent with complete nitrate depletion offshore in the Roper and Bangemall basins (unlike

755 in the Belt basin), several features of our results indicate that nitrate concentrations were

756 probably significantly lower than in the Paleoproterozoic, Neoproterozoic, and modern ocean. 
757 First, $\delta^{15} \mathrm{~N}$ values were below $+3 \%$ in offshore Mesoproterozoic sediments compared to $+4 \%$ o to $758+5 \%$ in the Cenozoic and modern (Tesdal et al., 2013; Algeo et al., 2014) (Fig. 6), which likely 759 reflects a mixture of two biological inputs from nitrate-assimilating organisms $\left(\delta^{15} \mathrm{~N}>0 \%\right)$ and 760 diazotrophs $\left(\delta^{15} \mathrm{~N} \sim 0 \%\right.$ ). The latter would not have been ecologically significant if nitrate had

761 been abundant because $\mathrm{N}_{2}$ fixation is energetically costly. Second, the lightest $\delta^{15} \mathrm{~N}_{\text {bulk }}$ data from

762 the peritidal facies suggest rapid nitrate depletion and domination by $\mathrm{N}_{2}$ fixers during temporary 763 restriction from the marine nitrate reservoir. This is consistent with microfossil evidence from

764 the Bangemall basin peritidal facies where Palaeopleurocapsa which resembles a modern genus 765 of nitrogen-fixing cyanobacteria (Section 2.1) is found (Buick and Knoll, 1999). Further support 766 comes from biomarker evidence from the late Mesoproterozoic Taoudeni basin (1.1 Ga), which 767 indicates that even some shallow waters during the Mesoproterozoic could have also been 768 deficient in oxidized nitrogen species (Blumenberg et al., 2012). Lastly, the variability in $\delta^{15} \mathrm{~N}$

769 throughout the basins is best explained by a small nitrate reservoir whose relative size and 770 isotopic composition were easily perturbed. Similar variability is seen in sulfur isotopes from the 771 Mesoproterozoic, which is interpreted as an artifact of a small sulfate reservoir (Kah et al., 2004;

772 Guo et al., 2015). It is likely that the magnitude of nitrogen speciation trends varied between 773 different basins; nevertheless all the currently available nitrogen isotope data point towards 774 generally low Mesoproterozoic nitrate concentrations in the surface ocean with a minimum in 775 offshore waters.

776 If so, then nitrogen availability may have contributed to the ecological distribution of 777 marine organisms. As photosynthetic eukaryotes are apparently outcompeted by prokaryotes in 778 nitrate-limited environments (Malone, 1980; Li et al., 1992; Lindell and Post, 1995; Latasa and 779 Bidigare, 1998; Karl et al., 2001; Bouman et al., 2011; Fawcett et al., 2011), it is likely that the 
open ocean was dominated by prokaryotic organisms with eukaryotes perhaps only inhabiting

781 the most oxygenated part of the water column. Nearer shore, a more diverse ecosystem including

782 abundant eukaryotes may have developed in relatively nitrate-rich waters. The very shallowest

783 peritidal settings may again have excluded eukaryotes, not because of anoxia but due to periodic

784 nitrate depletion during intervals of restricted water exchange at low tides. This ecological

785 gradient may have also had evolutionary consequences in that eukaryote diversification was not

786 possible in offshore and onshore nitrate-poor settings but was instead confined to near-shore

787 waters that were relatively nitrate-rich. It is also possible that eukaryotic life was inhibited

788 directly by episodic upwelling of anoxic and sometimes sulfidic waters (Johnston et al., 2009);

789 these two mechanisms of eukaryotic inhibition are not mutually exclusive and likely both

790 occurred. If so, then perhaps eukaryotes underwent a major evolutionary radiation and rise to

791 ecological dominance only after a Neoproterozoic oxygen increase, resulting in globally

792 prevalent nitrification and deeper or less widespread anoxic water masses. Thus, our data support

793 the hypothesis of Anbar \& Knoll (2002) that nitrogen may have been a key constraint on the

794 evolution of eukaryotes.

795

796 6. Conclusion

797 Nitrogen isotope data from the Bangemall and Roper basins, considered in concert with

798 the Belt basin (Stüeken, 2013), are consistent with the idea that distinct facies-dependent

799 nitrogen regimes (largely aerobic near-shore and partially to fully anaerobic offshore) were a

800 common feature in the early Mesoproterozoic. Peak enrichment in $\delta^{15} \mathrm{~N}_{\text {bulk }}$ occurs in shallow and

801 peritidal depositional environments and cannot solely be explained by post-depositional

802 alteration. There is no apparent systematic cross-basin bias of oxic versus anoxic diagenesis or 
803 metamorphism, so it is likely that these heavy values reflect the primary isotopic composition of

804 biomass forming in the water column. The most plausible explanation for positive $\delta^{15} \mathrm{~N}_{\text {bulk }}$

805 values in the shallower waters is that a pool of dissolved nitrate was partially denitrified and the

806 residual isotopically heavy nitrate was subsequently assimilated into biomass, as in the modern

807 ocean (e.g. Sigman et al., 2009a). Instances of light $\delta^{15} \mathrm{~N}_{\text {bulk }}$ in peritidal environments probably

808 represent transient periods of isolation from the marine nitrate supply at low tide leaving fixation

809 as the primary source of nitrogen. Light $\delta^{15} \mathrm{~N}_{\text {bulk }}$ values in deep water samples are consistent with

810 a predominance of $\mathrm{N}_{2}$ fixation by the Mo-based nitrogenase; slightly heavier samples likely

811 record mixing with biomass from nitrate assimilators during intervals when nitrate was more

812 available in the surface ocean, as in parts of the modern redox-stratified Cariaco basin (Montes et

813 al., 2013). Such mixing implies that nitrate concentrations were low, because any isotopic signal

814 from $\mathrm{N}_{2}$ fixation would be erased without a nitrate deficit in the water column (e.g. Fulton et al., 815 2012).

816 It is not clear whether the proposed spatial and temporal trends in nitrogen cycling

817 indicate reduced concentrations of trace metals, oxygen, or both in deep water environments

818 during the Mesoproterozoic where aerobic nitrogen cycling seems to have been limited. Our

819 results are consistent with metal-nitrogen co-limitation controlled by the extent of euxinic

820 conditions (Anbar and Knoll, 2002; Glass et al., 2009; Reinhard et al., 2013), but probably only

821 to a degree that limited nitrification and denitrification offshore while $\mathrm{N}_{2}$-fixation by the Mo-

822 based nitrogenase was able to persist. Our data are also consistent with a Mesoproterozoic

823 oxygen decline (Bekker and Holland, 2012; Planavsky et al., 2012; Partin et al., 2013; Scott et

824 al., 2014), as nitrogen isotopic ratios are lower in the Mesoproterozoic than in the Paleo- and

825 Neoproterozoic, suggesting relatively lower nitrate concentrations. A basinal gradient of 
826 dissolved oxygen concentrations (higher near-shore to lower offshore) could potentially also

827 produce the nitrogen isotopic trend seen in our datasets by limiting the extent of nitrification.

828 Thus the theoretical prediction of two spatially separated states of the nitrogen cycle in the mid-

829 Proterozoic (Boyle et al., 2013) is now expressed in three different Mesoproterozoic basins,

830 though how much this pattern directly depended on the location and extent of underlying euxinic

831 waters is still unclear. Regardless, such patterns would probably have restricted eukaryote

832 biomass and evolution to near-shore settings, as hypothesized by Anbar and Knoll (2002),

833 though the key limiting factor may not have been nitrogen fixation rates but nitrogen speciation.

834

835 Acknowledgements

836 We thank NSF EAR FESD grant \#1338810 (RB), NASA grant NNX16AI37G (RB), the

837 Agouron Institute (RB), the NASA Astrobiology Institute’s Virtual Planetary Laboratory (RB),

838 the NSF Graduate Research Fellowship Program (MAK), and the Department of Earth and Space

839 Sciences, University of Washington Goodspeed Geology Fellowship (MCK), Misch Fellowship

840 (MCK), and the Kenneth C. Robbins Field Study Fellowship (2014, MCK) for funding, Andrew

841 Schauer, Virginia Littell, and the University of Washington Isolab for technical support, and

842 Simon Poulton for three additional Roper Group samples. We also thank Chris Reinhard and two

843 anonymous reviewers and the associate editor James Farquhar for their comments that

844 significantly improved this paper.

845

\section{References}

847

848

849

850

Abbott, S.T. and Sweet, I.P., 2000. Tectonic control on third-order sequences in a siliciclastic ramp-style basin: an example from the Roper Superbasin (Mesoproterozoic), northern Australia. Australian Journal of Earth Sciences, 47: 637-657. 
851

852

853

854

855

856

857

858

859

860

861

862

863

864

865

866

867

868

869

870

871

872

873

874

875

876

877

878

879

880

881

882

883

884

885

886

887

888

889

890

891

892

893

894

895

Ader, M., Thomazo, C., Sansjofre, P., Busigny, V., Papineau, D., Laffont, R., Cartigny, P., and Halverson, G.P., 2016. Interpretation of the nitrogen isotopic composition of Precambrian sedimentary rocks: Assumptions and perspectives. Chemical Geology, 429: 93-110.

Ader, M., Sansjofre, P., Halverson, G.P., Busigny, V., Trindade, R.I., Kunzmann, M. and Nogueira, A.C., 2014. Ocean redox structure across the Late Neoproterozoic oxygenation event: A nitrogen isotope perspective. Earth and Planetary Science Letters, 396: 1-13.

Algeo, T.J., Meyers, P.A., Robinson, R.S., Rowe, H. and Jiang, G.Q., 2014. Icehousegreenhouse variations in marine denitrification. Biogeosciences, 11: 1273-1295.

Altabet, M.A. and Francois, R., 1994. Sedimentary nitrogen isotopic ratio as a recorder for surface ocean nitrate utilization. Global Biogeochemical Cycles, 8: 103-116.

Anbar, A., Duan, Y., Lyons, T.W., Arnold, G.L., Kendall, B., Creaser, R.A., Kaufman, A.J., Gordon, G.W., Scott, C.T., Garvin, J. and Buick, R., 2007. A whiff of oxygen before the Great Oxidation Event? Science, 317: 1903-1906.

Anbar, A.D. and Knoll, A.H., 2002. Proterozoic ocean chemistry and evolution: a bioinorganic bridge? Science, 297: 1137-1142.

Arnold, G.L., Anbar, A.D., Barling, J. and Lyons, T.W., 2004. Molybdenum isotope evidence for widespread anoxia in mid-Proterozoic oceans. Science, 304: 87-90.

Bartley, J.K. and Kah, L.C., 2004. Marine carbon reservoir, $\mathrm{C}_{\text {org }}-\mathrm{C}_{\text {carb }}$ coupling, and the evolution of the Proterozoic carbon cycle. Geology, 32: 129-132.

Bebout, G.E. and Fogel, M.L., 1992. Nitrogen-isotopic composition of metasedimentary rocks in the Catalina Schist, California: implications for metamorphic devolatilization history. Geochimica et Cosmochimica Acta, 56: 2839-2849.

Bekker, A. and Holland, H.D., 2012. Oxygen overshoot and recovery during the early Paleoproterozoic. Earth and Planetary Science Letters, 317: 295-304.

Bekker, A., Holland, H.D., Wang, P.-L., Rumble III, D., Stein, H.J., Hannah, J.L., Coetzee, L.L. and Beukes, N.J., 2004. Dating the rise of atmospheric oxygen. Nature, 427: 117-120.

Bekker, A., Holmden, C., Beukes, N.J., Kenig, F., Eglinton, B. and Patterson, W.P., 2008. Fractionation between inorganic and organic carbon during the Lomagundi $(2.22-2.1 \mathrm{Ga})$ carbon isotope excursion. Earth and Planetary Science Letters, 271: 278-291.

Blamey, N.J.F., Brand, U., Parnell, J., Spear, N., Lécuyer, C., Benisn, K., Meng, F., Ni, P., 2016. Paradigm shift in determining Neoproterozoic atmospheric oxygen. Geology, 44: 651654.

Blumenberg, M., Thiel, V., Riegel, W., Kah, L.C. and Reitner, J., 2012. Biomarkers of black shales formed by microbial mats, Late Mesoproterozoic $(1.1 \mathrm{Ga})$ Taoudeni Basin, Mauritania. Precambrian Research, 196: 113-127.

Bouman, H.A., Ulloa, O., Barlow, R., Li, W.K., Platt, T., Zwirglmaier, K., Scanlan, D.J. and Sathyendranath, S., 2011. Water-column stratification governs the community structure of subtropical marine picophytoplankton. Environmental Microbiology Reports, 3: 473482.

Boyle, R.A., Clark, J.R., Poulton, S.W., Shields-Zhou, G., Canfield, D.E. and Lenton, T.M., 2013. Nitrogen cycle feedbacks as a control on euxinia in the mid-Proterozoic ocean. Nature Communications, 4: doi:10.1038/ncomms2511.

Brookins, D.G., 1988. Eh-pH Diagrams for Geochemistry. Springer-Verlag, New York.

Brunner, B., Contreras, S., Lehmann, M.F., Matantseva, O., Rollog, M., Kalvelage, T., Klockgether, G., Lavik, G., Jetten, M.S.M., Kartal, B. and Kuypers, M.M., 2013. 
Nitrogen isotope effects induced by anammox bacteria. Proceedings of the National Academy of Sciences, 110: 18994-18999.

Buick, R., 2007. Did the Proterozoic 'Canfield Ocean' cause a laughing gas greenhouse? Geobiology, 5: 97-100.

Buick, R., Des Marais, D.J. and Knoll, A.H., 1995. Stable isotopic compositions of carbonates from the Mesoproterozoic Bangemall Group, northwestern Australia. Chemical Geology, 123: $153-171$.

Buick, R. and Knoll, A.H., 1999. Acritarchs and microfossils from the Mesoproterozoic Bangemall Group, northwestern Australia. Journal of Paleontology, 73: 744-764.

Busigny, V., Lebeau, O., Ader, M., Krapež, B. and Bekker, A., 2013. Nitrogen cycle in the Late Archean ferruginous ocean. Chemical Geology, 362: 115-130.

Canfield, D.E., and Teske, A., 1996. Late Proterozoic rise in atmospheric oxygen concentration inferred from phylogenetic and sulphur-isotope studies. Nature, 382: 127-132.

Canfield, D.E., 1998. A new model for Proterozoic ocean chemistry. Nature, 396: 450-453.

Canfield, D.E., Ngombi-Pemba, L., Hammarlund, E.U., Bengtson, S., Chaussidon, M., GauthierLafaye, F., Meunier, A., Riboulleau, A., Rollion-Bard, C., Rouxel, O., Asael, D., PiersonWickmann, A.-C. and El Albani, A., 2013. Oxygen dynamics in the aftermath of the Great Oxidation of Earth's atmosphere. Proceedings of the National Academy of Sciences, 110: 16736-16741.

Casciotti, K.L., 2009. Inverse kinetic isotope fractionation during bacterial nitrite oxidation. Geochimica et Cosmochimica Acta, 73: 2061-2076.

Cox, G.M., Jarrett, A., Edwards, D., Crockford, P.W., Halverson, G.P., Collins, A.S., Poirier, A., and Li, Z.X., 2016. Basin redox and primary productivity within the Mesoproterozoic Roper Seaway. Chemical Geology, 440: 101-114.

Cremonese, L., Shields-Zhou, G.A., Struck, U., Ling, H.F. and Och, L.M., 2014. Nitrogen and organic carbon isotope stratigraphy of the Yangtze Platform during the EdiacaranCambrian transition in South China. Palaeogeography, Palaeoclimatology, Palaeoecology, 398: 165-186.

Czaja, A.D., Johnson, C.M., Beard, B.L., Eigenbrode, J.L., Freeman, K.H. and Yamaguchi, K.E., 2010. Iron and carbon isotope evidence for ecosystem and environmental diversity in the 2.7 to 2.5 Ga Hamersley Province, Western Australia. Earth and Planetary Science Letters, 292: 170-180.

Donnelly, T.H. and Crick, I.H., 1988. Depositional environment of the middle Proterozoic Velkerri Formation in northern Australia: geochemical evidence. Precambrian Research, 42: 165-172.

Dutkiewicz, A., Volk, H., Ridley, J. and George, S., 2003. Biomarkers, brines, and oil in the Mesoproterozoic, Roper Superbasin, Australia. Geology, 31: 981-984.

Dutkiewicz, A., Volk, H., Ridley, J. and George, S.C., 2004. Geochemistry of oil in fluid inclusions in a middle Proterozoic igneous intrusion: implications for the source of hydrocarbons in crystalline rocks. Organic Geochemistry, 35: 937-957.

Eigenbrode, J.L. and Freeman, K.H., 2006. Late Archean rise of aerobic microbial ecosystems. Proceedings of the National Academy of Sciences, 103: 15759-15764.

Elston, D.P., Enkin, R.J., Baker, J. and Kisilevsky, D.K., 2002. Tightening the Belt: Paleomagnetic-stratigraphic constraints on deposition, correlation, and deformation of the Middle Proterozoic (ca. 1.4 Ga) Belt-Purcell Supergroup, United States and Canada. Geological Society of America Bulletin, 114: 619-638. 
Farquhar, J., Zerkle, A.L. and Bekker, A., 2011. Geological constraints on the origin of oxygenic photosynthesis. Photosynthesis research, 107: 11-36.

Fawcett, S.E., Lomas, M.W., Casey, J.R., Ward, B.B. and Sigman, D.M., 2011. Assimilation of upwelled nitrate by small eukaryotes in the Sargasso Sea. Nature Geoscience, 4: 717-722.

Flannery, E. N., and George, S. C., 2014. Assessing the syngeneity and indigeneity of hydrocarbons in the $\sim 1.4$ Ga Velkerri Formation, McArthur Basin, using slice experiments. Organic Geochemistry, 77: 115-125.

Freude, C., Blaser, M., 2016. Carbon isotope fractionation during catabolism and anabolism in acetogenic bacteria growing on different substrates. Applied and Environmental Microbiology, 82: 2728-2737.

Freudenthal, T., Wagner, T., Wenzhoefer, F., Zabel, M. and Wefer, G., 2001. Early diagenesis of organic matter from sediments of the eastern subtropical Atlantic: evidence from stable nitrogen and carbon isotopes. Geochimica et Cosmochimica Acta, 65: 1795-1808.

Frey, C., Hietanen, S., Jürgens, K., Labrenz, M. and Voss, M., 2014. N and O isotope fractionation in nitrate during chemolithoautotrophic denitrification by Sulfurimonas gotlandica. Environmental Science and Technology, 48: 13229-13237.

Fuchsman, C.A. and Murray, J.K., S.K., 2008. Concentration and natural stable isotope profiles of nitrogen species in the Black Sea. Marine Chemistry, 111: 90-105.

Fulton, J.M., Arthur, M.A. and Freeman, K.H., 2012. Black Sea nitrogen cycling and the preservation of phytoplankton $\delta 15 \mathrm{~N}$ signals during the Holocene. Global Biogeochemical Cycles, 26: DOI: 10.1029/2011GB004196.

Galbraith, E., Kienast, M. and NICOPP, 2013. The acceleration of oceanic denitrification during deglacial warming. Nature Geoscience, 6: 579-584.

Garvin, J., Buick, R., Anbar, A.D., Arnold, G.L. and Kaufman, A.J., 2009. Isotopic evidence for an aerobic nitrogen cycle in the latest Archean. Science, 323: 1045-1048.

Gilleaudeau, G.J. and Kah, L.C., 2013. Carbon isotope records in a Mesoproterozoic epicratonic sea: carbon cycling in a low-oxygen world. Precambrian Research, 228: 85-101.

Glass, J.B., Axler, R.P., Chandra, S. and Goldman, C.R., 2012. Molybdenum limitation of microbial nitrogen assimilation in aquatic ecosystems and pure cultures. Frontiers in Microbiology, 3: doi:10.3389/fmicb.2012.00331.

Glass, J.B., Wolfe-Simon, F. and Anbar, A.D., 2009. Coevolution of metal availability and nitrogen assimilation in cyanobacteria and algae. Geobiology, 7: 100-123.

Godfrey, L.V. and Falkowski, P.G., 2009. The cycling and redox state of nitrogen in the Archaean ocean. Nature Geoscience, 2: 725-729.

Godfrey, L.V. and Glass, J.B., 2011. The geochemical record of the ancient nitrogen cycle, nitrogen isotopes, and metal cofactors. Methods in Enzymology, 486: 483-506.

Godfrey, L.V., Poulton, S.W., Bebout, G.E. and Fralick, P.W., 2013. Stability of the nitrogen cycle during development of sulfidic water in the redox-stratified late Paleoproterozoic ocean. Geology, 41: 655-658.

Granger, J., Prokopenko, M.G., Sigman, D.M., Mordy, C.W., Morse, Z.M., Morales, L.V., Sambrotto, R.N. and Plessen, B., 2011. Coupled nitrification-denitrification in sediment of the eastern Bering Sea shelf leads to $15 \mathrm{~N}$ enrichment of fixed $\mathrm{N}$ in shelf waters. Journal of Geophysical Research: Oceans, 116: doi: 10.1029/2010JC006751.

Gregory, D.D., Large, R.R., Halpin, J.A., Steadman, J.A., Hickman, A.H., Ireland, T.R. and Holden, P., 2015. The chemical conditions of the late Archean Hamersley basin inferred 
1006

1007

1008

1009

1010

1011

1012

1013

1014

1015

1016

1017

1018

1019

1020

1021

1022

1023

1024

1025

1026

1027

1028

1029

1030

1031

from whole rock and pyrite geochemistry with $\Delta^{33} \mathrm{~S}$ and $\delta^{34} \mathrm{~S}$ isotope analyses. Geochimica et Cosmochimica Acta, 149: 223-250.

Guo, H., Du, Y., Kah, L.C., Hu, C., Huang, J., Huang, H., Yu, W. and Song, H., 2015. Sulfur isotope composition of carbonate-associated sulfate from the Mesoproterozoic Jixian Group, North China: Implications for the marine sulfur cycle. Precambrian Research, 266: 319-336.

Guo, H., Du, Y., Kah, L.C., Huang, J., Hu, C., Huang, H. and Yu, W., 2013. Isotopic composition of organic and inorganic carbon from the Mesoproterozoic Jixian Group, North China: Implications for biological and oceanic evolution. Precambrian Research, 224: 169-183.

Haendel, D., Muehle, K., Nitzsche, H.-M., Stiehl, G. and Wand, U., 1986. Isotopic variations of the fixed nitrogen in metamorphic rocks. Geochimica et Cosmochimica Acta, 50: 749758.

Hardisty, D.S., Lu, Z., Planavsky, N.J., Bekker, A., Philippot, P., Zhou, X. and Lyons, T.W., 2014. An iodine record of Paleoproterozoic surface ocean oxygenation. Geology, 42: 619-622.

Haug, G.H., Pedersen, T.F., Sigman, D.M., Calvert, S.E., Nielsen, B. and Peterson, L.C., 1998. Glacial/interglacial variations in production and nitrogen fixation in the Cariaco Basin during the last 580 kyr. Paleoceanography, 13: 427-432.

Hayes, J.M., 2001. Fractionation of carbon and hydrogen isotopes in biosynthetic processes. Reviews in Mineralogy and Geochemistry, 43: 225-277.

Hayes, J.M., Kaplan, I.R. and Wedeking, K.W., 1983. Precambrian organic geochmistry, preservation of the record. In: J.W. Schopf (Editor), Earth's earliest biosphere - its origin and evolution. Princeton University Press, Princeton, NJ, pp. 93-134.

Hoefs, J. and Frey, M., 1976. The isotopic composition of carbonaceous matter in a metamorphic profile from the Swiss Alps. Geochimica et Cosmochimica Acta, 40: 945-951.

Idnurm, M., Giddings, J.W. and Plumb, K.A., 1995. Apparent polar wander and reversal stratigraphy of the Palaeo-Mesoproterozoic southeastern McArthur Basin, Australia. Precambrian Research, 72: 1-41.

Jackson, M.J. and Raiswell, R., 1991. Sedimentoogy and carbon-sulphur geochemistry of the Velkerri Formation, a mid-Proterozoic potential oil source in northern Australia. Precambrian Research, 54: 81-108.

Jackson, M.J., Sweet, I.P. and Powell, T.G., 1988. Studies on Petroleum geology and geochemistry, Middle Proterozoic, McArthur Basin, northern Australia: I. Petroleum potential. APEA J, 28: 283-302.

Javaux, E.J., Knoll, A.H. and Walter, M.R., 2001. Morphological and ecological complexity in early eukaryotic ecosystems. Nature, 412: 66-69.

Javaux, E.J., Knoll, A.H. and Walter, M.R., 2004. TEM evidence for eukaryotic diversity in midProterozoic oceans. Geobiology, 2: 121-132.

Jia, Y., 2006. Nitrogen isotope fractionations during progressive metamorphism: a case study from the Paleozoic Cooma metasedimentary complex, southeastern Australia. Geochimica et Cosmochimica Acta, 70: 5201-5214.

Johnston, D.T., Farquhar, J., Summons, R.E., Shen, Y., Kaufman, A.J., Masterson, A.L. and Canfield, D.E., 2008. Sulfur isotope biogeochemistry of the Proterozoic McArthur Basin. Geochimica et Cosmochimica Acta, 72: 4278-4290. 
1032

1033

1034

1035

1036

1037

1038

1039

1040

1041

1042

1043

1044

1045

1046

1047

1048

1049

1050

1051

1052

1053

1054

1055

1056

1057

1058

1059

1060

1061

1062

1063

1064

1065

1066

1067

1068

1069

1070

1071

1072

1073

1074

1075

1076

1077

Johnston, D.T., Wolfe-Simon, F., Pearson, A. and Knoll, A.H., 2009. Anoxygenic photosynthesis modulated Proterozoic oxygen and sustained Earth's middle age. Proceedings of the National Academy of Sciences, 106: 16925-16929.

Junium, C.K. and Arthur, M.A., 2007. Nitrogen cycling during the Cretaceous, CenomanianTuronian Oceanic Anoxic Event II. Geochemistry Geophysics Geosystems, 8: doi: 10.1029/2006GC001328.

Kah, L.C., Lyons, T.W. and Frank, T.D., 2004. Low marine sulphate and protracted oxygenation of the Proterozoic biosphere. Nature, 431: 834-838.

Karl, D.M., Bidigare, R.R. and Letelier, R.M., 2001. Long-term changes in plankton community structure and productivity in the North Pacific Subtropical Gyre: the domain shift hypothesis. Deep Sea Research Part II: Topical Studies in Oceanography, 48: 1449-1470.

Kendall, B., Creaser, R.A., Gordon, G.W. and Anbar, A., 2009. Re-Os and Mo isotope systematics of black shales from the middle Proterozoic Velkerri and Wollogoran formations, McArthur basin, northern Australia. Geochimica et Cosmochimica Acta, 73: 2534-2558.

Kendall, B., Reinhard, C.T., Lyons, T.W., Kaufman, A.J., Poulton, S.W. and Anbar, A., 2010. Pervasive oxygenation along late Archaean ocean margins. Nature Geoscience, 3: 647652.

Kessler, A.J., Bristow, L.A., Cardenas, M.B., Glud, R.N., Thamdrup, B. and Cook, P.L., 2014. The isotope effect of denitrification in permeable sediments. Geochimica et Cosmochimica Acta, 133: 156-167.

Kikumoto, R., Tahata, M., Nishizawa, M., Sawaki, Y., Maruyama, S., Shu, D., Han, J., Komiya, T., Takai, K. and Ueno, Y., 2014. Nitrogen isotope chemostratigraphy of the Ediacaran and Early Cambrian platform sequence at Three Gorges, South China. Gondwana Research, 25: 1057-1069.

Kralik, M., 1982. Rb-Sb age determinations on Precambrian carbonate rocks of the Carpentarian McArthur basin, Northern Territories, Australia. Precambrian Research, 18: 157-170.

Kump, L.R., Junium, C., Arthur, M.A., Brasier, A., Fallick, A., Melezhik, V., Lepland, A., CČrne, A.E. and Luo, G., 2011. Isotopic evidence for massive oxidation of organic matter following the Great Oxidation Event. Science, 334: 1694-1696.

Kurzweil, F., Claire, M.W., Thomazo, C., Peters, M., Hannington, M. and Strauss, H., 2013. Atmospheric sulfur rearrangement 2.7 billion years ago: Evidence for oxygenic photosynthesis. Earth and Planetary Science Letters, 366: 17-26.

Kurzweil, F., Wille, M., Schoenberg, R., Taubald, H. and van Kranendonk, M.J., 2015. Continuously increasing $\delta^{98}$ Mo values in Neoarchean black shales and iron formations from the Hamersley Basin. Geochimica et Cosmochimica Acta, 164: 523-542.

LaPorte, D.F., Holmden, C., Patterson, W.P., Loxton, J.D., Melchin, M.J., Mitchell, C.E., Finney, S.C. and Sheets, H.D., 2009. Local and global perspectives on carbon and nitrogen cycling during the Hirnantian glaciation. Palaeogeography Palaeoclimatology Palaeoecology, 276: 182-195.

Latasa, M. and Bidigare, R.R., 1998. A comparison of phytoplankton populations of the Arabian Sea during the Spring Intermonsoon and Southwest Monsoon of 1995 as described by HPLC-analyzed pigments. Deep Sea Research Part II: Topical Studies in Oceanography, 45: 2133-2170.

Lehman, M.R., Bernasconi, S.M., Barbieri, A. and McKenzie, J.A., 2002. Preservation of organic matter and alteration of its carbon and nitrogen isotope composition during 
simulated and in situ early sedimentary diagenesis. Geochimica et Cosmochimica Acta, 66: 3573-3584.

Li, W.K.W., Dickie, P.M., Irwin, B.D. and Wood, A.M., 1992. Biomass of bacteria, cyanobacteria, prochlorophytes and photosynthetic eukaryotes in the Sargasso Sea. Deep Sea Research Part A. Oceanographic Research Papers, 39: 501-519.

Lindell, D. and Post, A.F., 1995. Ultraphytoplankton succession is triggered by deep winter mixing in the Gulf of Aqaba (Eilat), Red Sea. Limnology and Oceanography, 40: 11301141.

Luepke, J.J. and Lyons, T.W., 2001. Pre-Rodinian (Mesoproterozoic) supercontinental rifting along the western margin of Laurentia: geochemical evidence from the Belt-Purcell Supergroup. Precambrian Research, 111: 79-90.

Luo, G., Hallmann, C., Xie, S., Ruan, X. and Summons, R.E., 2015. Comparative microbial diversity and redox environments of black shale and stromatolite facies in the Mesoproterozoic Xiamaling Formation. Geochimica et Cosmochimica Acta, 151: 150167.

Luo, G., Ono, S., Huang, J., Algeo, T.J., Li, C., Zhou, L., Robinson, A., Lyons, T.W. and Xie, S., 2014. Decline in oceanic sulfate levels during the early Mesoproterozoic. Precambrian Research, 258: 36-47.

Lydon, J.W., 2007. Geology and metallogeny of the Belt-Purcell basin. In: W.D. Goodfellow (Editor), Mineral deposits of Canada: a synthesis of major deposit-types, district metallogeny, the evolution of geological provinces, and exploration methods. Geological Association of Canada, Mineral Deposits Division, Special Publication, pp. 581-607.

Lyons, T.W., Reinhard, C.T. and Planavsky, N.J., 2014. The rise of oxygen in Earth's early ocean and atmosphere. Nature, 506: 307-315.

Macko, S.A. and Estep, M.L., 1984. Microbial alteration of stable nitrogen and carbon isotopic compositions of organic matter. Organic Geochemistry, 6: 787-790.

Macko, S.A., Fogel, M.L., Hare, P.E. and Hoering, T.C., 1987. Isotopic fractionation of nitrogen and carbon in the synthesis of amino acids by microorganisms. Chemical Geology, 65: 79-92.

Malone, T.C., 1980. Size-fractionated primary productivity of marine phytoplankton. In: P.G. Falkowski (Editor), Primary productivity in the sea. Springer US, pp. 301-319.

Martin, D.M., 2002. Peperite in the Backdoor Formation and its significance to the age and tectonic evolution of the Bangemall Supergroup. Western Australia Geological Survey Annual Review, 2002: 53-59.

Martin, D.M., Sircombe, K.N., Thorne, A.M., Cawood, P.A. and Nemchin, A.A., 2008. Provenance history of the Bangemall Supergroup and implications for the Mesoproterozoic paleogeography of the West Australian Craton. Precambrian Research, 166: 93-110.

Martin, D.M. and Thorne, A.M., 2004. Tectonic setting and basin evolution of the Bangemall Supergroup in the northwestern Capricorn Orogen. Precambrian Research, 128: 385-409.

McKirdy, D.M. and Powell, T.G., 1974. Metamorphic alteration of carbon isotopic composition in ancient sedimentary organic matter: new evidence from Australia and South Africa. Geology, 2: 591-595.

Montes, E., Thunell, R., Muller-Karger, F.E., Lorenzoni, L., Tappa, E., Troccoli, L., Astor, Y. and Varela, R., 2013. Sources of $\delta^{15} \mathrm{~N}$ variability in sinking particulate nitrogen in the 
Cariaco Basin, Venezuela. Deep Sea Research Part II: Topical Studies in Oceanography, 93: 96-107.

Morales, L.V., Granger, J., Chang, B.X., Prokopenko, M.G., Plessen, B., Gradinger, R. and Sigman, D.M., 2014. Elevated ${ }^{15} \mathrm{~N} /{ }^{14} \mathrm{~N}$ in particulate organic matter, zooplankton, and diatom frustule-bound nitrogen in the ice-covered water column of the Bering Sea eastern shelf. Deep Sea Research Part II: Topical Studies in Oceanography, 109: 100-111.

Nishizawa, M., Miyazaki, J., Makabe, A., Koba, K. and Takai, K., 2014. Physiological and isotopic characteristics of nitrogen fixation by hyperthermophilic methanogens: Key insights into nitrogen anabolism of the microbial communities in Archean hydrothermal systems. Geochimica et Cosmochimica Acta, 138: 117-135.

Ohkouchi, N., Kashiyama, Y., Kuroda, J., Ogawa, N.O. and Kitazato, H., 2006. The importance of diazotrophic cyanobacteria as primary producers during Cretaceous Oceanic Anoxic Event 2. Biogeosciences, 3: 467-478.

Olson, S.L., Kump, L.R. and Kasting, J.F., 2013. Quantifying the areal extent and dissolved oxygen concentrations of Archean oxygen oases. Chemical Geology, 362: 35-43.

Page, R.W., Jackson, M.J. and Krassay, A.A., 2000. Constraining sequence stratigraphy in north Australian basins: SHRIMP U-Pb zircon geochronology between Mt Isa and McArthur River. Australian Journal of Earth Sciences, 47: 431-459.

Papineau, D., Purohit, R., Fogel, M.L. and Shields-Zhou, G.A., 2013. High phosphate availability as a possible cause for massive cyanobacterial production of oxygen in the Paleoproterozoic atmosphere. Earth and Planetary Science Letters, 362: 225-236.

Papineau, D., Purohit, R., Goldberg, T., Pi, D., Shields, G.A., Bhu, H., Steele, A. and Fogel, M.L., 2009. High primary productivity and nitrogen cycling after the Paleoproterozoic phosphogenic event in the Aravalli Supergroup, India. Precambrian Research, 171: 3756.

Partin, C.A., Lalonde, S.V., Planavsky, N.J., Bekker, A., Rouxel, O.J., Lyons, T.W. and Konhauser, K.O., 2013. Uranium in iron formations and the rise of atmospheric oxygen. Chemical Geology, 362: 82-90.

Pavlov, A.A. and Kasting, J.F., 2002. Mass-independent fractionation of sulfur isotopes in Archean sediments: strong evidence for an anoxic Archean atmosphere. Astrobiology, 2: 27-41.

Peat, C.J., Muir, M.D., Plumb, K.A., McKirdy, D.M. and Norvick, M.S., 1978. Proterozoic microfossils from the Roper Group, Northern Territory, Australia. BMR Journal of Australian Geology and Geophysics, 3: 1-17.

Planavsky, N.J., Bekker, A., Hofmann, A., Owens, J.D. and Lyons, T.W., 2012. Sulfur record of rising and falling marine oxygen and sulfate levels during the Lomagundi event. Proceedings of the National Academy of Sciences, 109: 18300-18305.

Planavsky, N.J., McGoldrick, P., Scott, C.T., Li, C., Reinhard, C.T., Kelly, A.E., Chu, X., Bekker, A., Love, G.D. and Lyons, T.W., 2011. Widespread iron-rich conditions in the mid-Proterozoic ocean. Nature, 477: 448-451.

Planavsky, N.J., Reinhard, C.T., Wang, X., Thomson, D., McGoldrick, P., Rainbird, R.H., Johnson, T., Fischer, W.W. and Lyons, T.W., 2014. Low Mid-Proterozoic atmospheric oxygen levels and the delayed rise of animals. Science, 346: 635-638.

Poulin, F.J., and Franks, P.J.S., 2010. Size-structured planktonic ecosystems: constraints, controls and assembly instructions. Journal of Plankton Research, 32: 1121-1130. 
1168

1169

1170

1171

1172

1173

1174

1175

1176

1177

1178

1179

1180

1181

1182

1183

1184

1185

1186

1187

1188

1189

1190

1191

1192

1193

1194

1195

1196

1197

1198

1199

1200

1201

1202

1203

1204

1205

1206

1207

1208

1209

1210

1211

1212

Poulton, S.W. and Canfield, D.E., 2011. Ferruginous conditions: a dominant feature of the ocean through Earth's history. Elements, 7: 107-112.

Pratt, B.R., 2001. Oceanography, bathymetry and syndepositional tectonics of a Precambrian intracratonic basin: integrating sediments, storms, earthquakes and tsunamis in the Belt Supergroup (Helena Formation, ca. 1.45 Ga), western North America. Sedimentary Geology, 141-142: 371-394.

Qi, H., Coplen, T.B., Geilmann, H., Brand, W.A. and Böhlke, J.K., 2003. Two new organic reference materials for $\delta^{13} \mathrm{C}$ and $\delta^{15} \mathrm{~N}$ measurements and a new value for the $\delta^{13} \mathrm{C}$ of NBS 22 oil. Rapid Communications in Mass Spectrometry, 17: 2483-2487.

Quan, T.M. and Falkowski, P.G., 2009. Redox control of N:P ratios in aquatic ecosystems. Geobiology, 7: 124-139.

Rau, G.H., Arthur, M.A. and Dean, W.E., 1987. 15N/14N variations in Cretaceous Atlantic sedimentary sequences: implications for past changes in marine nitrogen biogeochemistry. Earth and Planetary Science Letters, 82: 269-279.

Reinhard, C.T., Planavsky, N.J., Robbins, L.J., Partin, C.A., Gill, B.C., Lalonde, S.V., Bekker, A., Konhauser, K.O. and Lyons, T.W., 2013. Proterozoic ocean redox and biogeochemical stasis. Proceedings of the National Academy of Sciences, 110: 53575362.

Reinhard, C.T., Raiswell, R., Scott, C.T., Anbar, A. and Lyons, T.W., 2009. A late Archean sulfidic sea stimulated by early oxidative weatheringn of the continents. Science, 326: 713-716.

Rivera, K.T., Puckette, J. and Quan, T.M., 2015. Evaluation of redox versus thermal maturity controls on $\delta 15 \mathrm{~N}$ in organic rich shales: A case study of the Woodford Shale, Anadarko Basin, Oklahoma, USA. Organic Geochemistry, 83: 127-139.

Robinson, R.S., Kienast, M., Albuquerque, A.L., Altabet, M., Contreras, S., De Pol Holz, R., Dubois, N., Francois, R., Galbraith, E., Shu, T.-C., Ivanochko, T., Jaccard, S., Kao, S.-J., Kiefer, T., Kienast, S., Lehmann, M., Martinez, P., McCarthy, M., Moebius, J., Pedersen, T., Quan, T.M., Ryabenko, E., Schmittner, A., Schneider, R., Schneider-Mor, A., Shigemitsu, M., Sinclair, D., Somes, C., Studer, A., Thunell, R. and Yang, J.-Y., 2012. A review of nitrogen isotopic alteration in marine sediments. Paleoceanography, 27: doi: 10.1029/2012PA002321.

Robl, T.L. and Davis, B.H., 1993. Comparison of the HF-HCl and HF-BF 3 maceration techniques and the chemistry of resultant organic concentrates. Organic Geochemistry, 20: 249-255.

Rooze, J. and Meilie, C., 2016. The effect of redox conditions and bioirrigation on nitrogen isotope fractionation in marine sediments. Geochimica et Cosmochimica Acta, 184: 227239.

Saito, M.A., Sigman, D.M. and Morel, F.M.M., 2003. The bioinorganic chemistry of the ancient ocean: the co-evolution of cyanobacterial metal requirements and biogeochemical cycles at the Archean-Proterozoic boundary? Inorganica Chimica Acta, 356: 308-318.

Schidlowski, M., 1987. Application of stable carbon isotopes to early biochemical evolution on Earth. Annual Review of Earth and Planetary Sciences, 15: 47-72.

Schoepfer, S.D., Henderson, C.M., Garrison, G.H. and Ward, P.D., 2012. Cessation of a productive coastal upwelling system in the Panthalassic Ocean at the Permian-Triassic Boundary. Palaeogeography, Palaeoclimatology, Palaeoecology, 313-314: 181-188. 
Scott, C., Wing, B.A., Bekker, A., Planavsky, N.J., Medvedev, P., Bates, S.M., Yun, M. and Lyons, T.W., 2014. Pyrite multiple-sulfur isotope evidence for rapid expansion and contraction of the early Paleoproterozoic seawater sulfate reservoir. Earth and Planetary Science Letters, 389: 95-104.

Sephton, M.A., Amor, K., Franchi, I.A., Wignall, P.B., Newton, R. and Zonneveld, J.-P., 2002. Carbon and nitrogen isotope disturbances and an end-Norian (Late Triassic) extinction event. Geology, 30: 1119-1122.

Shen, Y., Knoll, A.H. and Walter, M.R., 2003. Evidence for low sulphate and anoxia in a midProterozoic marine basin. Nature, 423: 632-635.

Siebert, C., Kramers, J.D., Meisel, T., Morel, P. and Naegler, T.F., 2005. PGE, Re-Os, and Mo isotope systematics in Archean and early Proterozoic sedimentary systems as proxies for redox conditions of early Earth. Geochimica et Cosmochimica Acta, 69: 1787-1801.

Sigman, D.M., Altabet, M.A., McCorkle, D.C., Francois, R. and Fischer, G., 2000. The $\delta 15 \mathrm{~N}$ of nitrate in the southern ocean: nitrogen cycling and circulation in the ocean interior. Journal of Geophysical Research: Oceans, 105: 19599-19614.

Sigman, D.M., DiFiore, P.J., Hain, M.P., Deutsch, C., Wang, Y., Karl, D.M., Knappe, A.N., Lehman, M.F. and Pantoja, S., 2009a. The dual isotope of deep nitrate as a constraint on the cycle and budget of oceanic fixed nitrogen. Deep Sea Research Part I, 56: 1419-1439.

Sigman, D.M., Karsh, K.L. and Casciotti, K.L., 2009b. Ocean process tracers: nitrogen isotopes in the ocean, Encyclopedia of ocean science. Elsevier, Amsterdam, pp. 4138-4153.

Siljeström, S., Volk, H., George, S. C., Lausmaa, J., Sjövall, P., Dutkiewicz, A., and Hode, T., 2013. Analysis of single oil-bearing fluid inclusions in mid-Proterozoic sandstones (Roper Group, Australia). Geochimica et Cosmochimica Acta, 122: 448-463.

Sperling, E.A., Wolock, C.J., Morgan, A.S., Gill, B.C., Kunzmann, M., Halverson, G.P., Macdonald, F.A., Knoll, A.H. and Johnston, D.T., 2015. Statistical analysis of iron geochemical data suggests limited late Proterozoic oxygenation. Nature, 523: 451-454.

Stüeken, E.E., 2013. A test of the nitrogen-limitation hypothesis for retarded eukaryote radiation: nitrogen isotopes across a Mesoproterozoic basinal profile. Geochimica et Cosmochimica Acta, 120: 121-139.

Stüeken, E.E., Buick, R. and Guy, B.M., 2015a. Isotopic evidence for biological nitrogen fixation by Mo-nitrogenase at 3.2 Gyr. Nature, 520: 666-669.

Stüeken, E.E., Buick, R. and Anbar, A.D., 2015b. Selenium isotopes support free O2 in the latest Archean. Geology, 43: 259-262.

Stüeken, E.E., Catling, D.C. and Buick, R., 2012. Contributions to late Archaean sulphur cycling by life on land. Nature Geoscience, 5: 722-725.

Stüeken, E.E., Kipp, M.A., Koehler, M.C., and Buick, R., 2016. The evolution of Earth's biogeochemical nitrogen cycle. Earth-Science Reviews, 160: 220-239.

Summons, R.E., Powell, T.G. and Boreham, C.J., 1988. Petroleum geology and geochemistry of the Middle Proterozoic McArthur Basin, Northern Australia: III. Composition of extractable hydrocarbons. Geochimica et Cosmochimica Acta, 52: 1747-1763.

Symons, D.T.A., 1966. A paleomagnetic study on the Gunflint, Mesabi, and Cuyuna iron ranges in the Lake Superior region. Economic Geology, 61: 1336-1361.

Tesdal, J.E., Galbraith, E.D. and Kienast, M., 2013. Nitrogen isotopes in bulk marine sediment: linking seafloor observations with subseafloor records. Biogeosciences, 10: 101-118.

Thomazo, C. and Papineau, D., 2013. Biogeochemical cycling of nitrogen on the early Earth. Elements, 9: 345-351. 
Thomson, D., Rainbird, R.H., Planavsky, N., Lyons, T.W., Bekker, A., 2015. Chemostratigraphy of the Shaler Supergroup, Victoria Island, NW Canada: A record of ocean composition prior to the Cryogenian glaciation. Precambrian Research, 263: 232-245.

Thunell, R.C., Sigman, D.M., Muller-Karger, F., Astor, Y. and Varela, R., 2004. Nitrogen isotope dynamics of the Cariaco Basin, Venezuela. Global Biogeochemical Cycles, 18: DOI: $10.1029 / 2003 G B 002185$.

Volk, H., George, S.C., Dutkiewicz, A. and Ridley, J., 2005. Characterisation of fluid inclusion oil in a Mid-Proterozoic sandstone and dolerite (Roper Superbasin, Australia). Chemical Geology, 223: 109-135.

Wang, X., Shi, X., Tang, D. and Zhang, W., 2013. Nitrogen isotope evidence for redox variations at the Ediacaran-Cambrian transition in South China. The Journal of Geology, 121: 489-502.

Wille, M., Kramers, J.D., Naegler, T.F., Beukes, N.J., Schroeder, S., Meisel, T., Lacassie, J.P. and Voegelin, A.R., 2007. Evidence for a gradual rise of oxygen between 2.6 and $2.5 \mathrm{Ga}$ from Mo isotopes and Re-PGE signatures in shales. Geochimica et Cosmochimica Acta, 71: 2417-2435.

Wingate, M.T.D., 2002. Age and palaeomagnetism of dolerite sills of the Bangemall Supergroup on the Edmund 1:250,000 map sheet, WA. Western Australia Geological Survey Record, 2002/4.

Winston, D., 1990. Evidence for intracratonic, fluvial and lacustrine settings of middle to late Proterozoic basins of western USA. In: C.F. Gower, T. Rivers and B. Ryan (Editors), Mid-Proterozoic Laurentia-Baltica. Geological Association Canada, Special Papers, pp. 535-564.

Yamaguchi, K.E., 2002. Geochemistry of Archean-Paleoproterozoic black shales: the early evolution of the atmosphere, oceans, and biosphere. PhD dissertation, Pennsylvania State University, 485 pp.

Zerkle, A., Junium, C.K., Canfield, D.E. and House, C.H., 2008. Production of ${ }^{15} \mathrm{~N}$-depleted biomass during cyanobacterial $\mathrm{N}_{2}$-fixation at high Fe concentrations. Journal of Geophysical Research: Biogeosciences, 113: doi: 10.1029/2007JG000651.

Zerkle, A.L., Claire, M.W., Domagal-Goldman, S.D., Farquhar, J. and Poulton, S.W., 2012. A bistable organic-rich atmosphere on the Neoarchaean Earth. Nature Geoscience, 5: 359363.

Zerkle, A.L., House, C.H., Cox, R.P. and Canfield, D.E., 2006. Metal limitation of cyanobacterial N2 fixation and implications for the Precambrian nitrogen cycle. Geobiology, 4: 285-297.

Zhang, X., Sigman, D.M., Morel, F.M. and Kraepiel, A.M., 2014. Nitrogen isotope fractionation by alternative nitrogenases and past ocean anoxia. Proceedings of the National Academy of Sciences, 111: 4782-4787.

Zhang, S., Wang, X., Wang, H., Bjerrum, C.J., Hammarlund, E.U., Costa, M.M., Connelly, J.N., Zhang, B., Su, J. and Canfield, D.E., 2016. Sufficient oxygen for animal respiration 1,400 million years ago. Proceedings of the National Academy of Sciences, 113: 1731-1736.

Zi, J.W., Rasmussen, B., Muhling, J.R., Fletcher, I.R., Thorne, A.M., Johnson, S.P., Cutten, H.N., Dunkley, D.J. and Korhonen, F.J., 2015. In situ U-Pb geochronology of xenotime and monazite from the Abra polymetallic deposit in the Capricorn Orogen, Australia: Dating hydrothermal mineralization and fluid flow in a long-lived crustal structure. Precambrian Research, 260: 91-112. 
Figure 1: Average nitrogen isotopic composition of bulk marine sedimentary rocks from offshore environments. Data are compiled from the literature (see Stüeken et al., 2015 for references) and from this study. Each point represents a time-point average, the black solid line marks the running mean over three points. Where no basinal gradient is present, all data were used. Samples from hydrothermal cherts and amphibolite facies were excluded.

Figure 2: Locations of the Bangemall Supergroup and Roper Group (boxes) and the approximate locations of sample collection (dots).

Figure 3: Stratigraphic $\delta^{15} \mathbf{N}_{\text {bulk }}$ plots of Bangemall transects. (A) Fords Creek, (B) Irregully, (C) Wandarry. Depositional facies in each panel are as in panel (D), with deep subtidal above the top dot-dash line, shallow subtidal in the middle, and peritidal below the bottom dot-dash line. Panel (D) is a normalized compilation of all the Bangemall transects where the positions of each point are relative to the thickness of the shallow subtidal facies. The red line indicates the running mean over three points.

Figure 4: $\delta^{15} \mathrm{~N}_{\text {kerogen }}$ vs. TOC/ $\mathrm{N}_{\text {kerogen }}$ (total organic carbon / kerogen-bound nitrogen) for Bangemall (yellow diamonds) and Roper (black circle) samples.

Figure 5: $\delta^{15} \mathrm{~N}_{\text {bulk }}$ plotted against $\delta^{13} \mathrm{C}_{\text {org }}$ for the Bangemall (A) and Roper (B) basins. The plot also includes those samples from the Bangemall basin that do not belong to one of the three main transects shown in Fig. 3A-C. Error bars are $\pm 1 \sigma$.

Figure 6: Histogram of Proterozoic offshore $\delta^{\mathbf{1 5}} \mathbf{N}_{\text {bulk }}$ data. (A) Neoproterozoic era (1.0-0.548 Ga) with data from Ader et al. (2014) and Kikumoto et al. (2014); (B) Mesoproterozoic era (1.6$1.0 \mathrm{Ga}$ ) with data from Stüeken (2013), Luo et al. (2015) and this study; (C) Paleoproterozoic era (2.5-1.6 Ga) with data from Busigny et al. (2013), Kump et al. (2011) and Godfrey et al. (2013). Subsets of the datasets listed above were taken to only include offshore environments: from Ader et al. (2014) the Camil, Carmelo, and Copacel sections from Brazil and all data from Svalbard and North Canada. From Kikumoto et al. (2014) all data from the Doushantuo Formation. From Stüeken (2013) data from the Newland Formation in Deep Creek. From the Bangemall and Roper of this study, “deep” and "basinal” data respectively. From Luo et al. (2015) all data. From Busigny et al. (2013) data from the Brockman Iron Formation. From Kump et al. (2011) data from above 180 meters in core depth (from $0 \mathrm{~m}$ to $180 \mathrm{~m}$ ). From Godfrey et al. (2013) data from cores MGS-7 and MGS-8. The inset in panel A shows modern marine sediment data from Tesdal et al. (2013). The modern data show no correlation with water depth and are therefore not separated by facies. Paleoproterozoic data from the Aravalli Group (Papineau et al., 2009; Papineau et al., 2013) were excluded because they are of higher metamorphic grade and their depositional environment is uncertain. 
1348 Figure 7: Schematic of the proposed Mesoproterozoic nitrogen cycle. Shown are fluxes (F) 1349 both in and out of a shallow water nitrate reservoir as we propose for the Bangemall and Roper 1350 basins. Blue flux arrows represent fluxes that, when varied, are most likely able to change the 1351 isotopic composition of a relatively small nitrate reservoir. All other fluxes are unlikely to 1352 change the isotopic composition of the nitrate reservoir. Flux labels are as follows: $F_{\text {fixation }}=\mathrm{N}_{2}$ 1353 fixation flux, $\mathrm{F}_{\text {nitri. }}=$ nitrification of organic matter to nitrate, $\mathrm{F}_{\text {assim. }}=$ assimilation of nitrate into 1354 biomass, $\mathrm{F}_{\text {den.wc. }}=$ water-column denitrification, $\mathrm{F}_{\text {den.sed. }}=$ sedimentary denitrification, $\mathrm{F}_{\text {upwell }}=$ 1355 upwelling of ammonium from anoxic waters. 


\section{Figures}

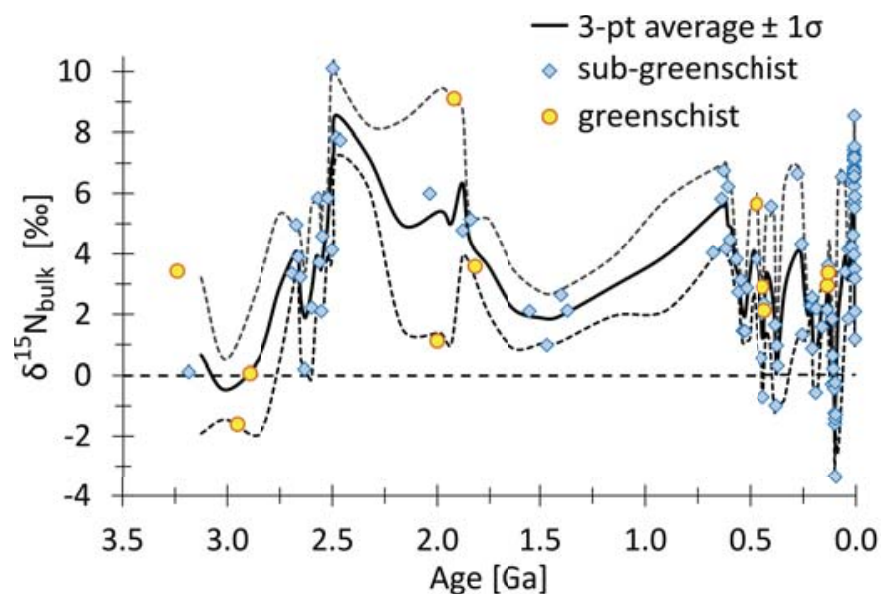

Figure 1: Average nitrogen isotopic composition of bulk marine sedimentary rocks from offshore environments. Data are compiled from the literature (see Stuieken et al., 2015 for references) and from this study. Each point represents a time-point average, the black solid line marks the running mean over three points. Where no basinal gradient is present, all data were used. Samples from hydrothermal cherts and amphibolite facies were excluded.

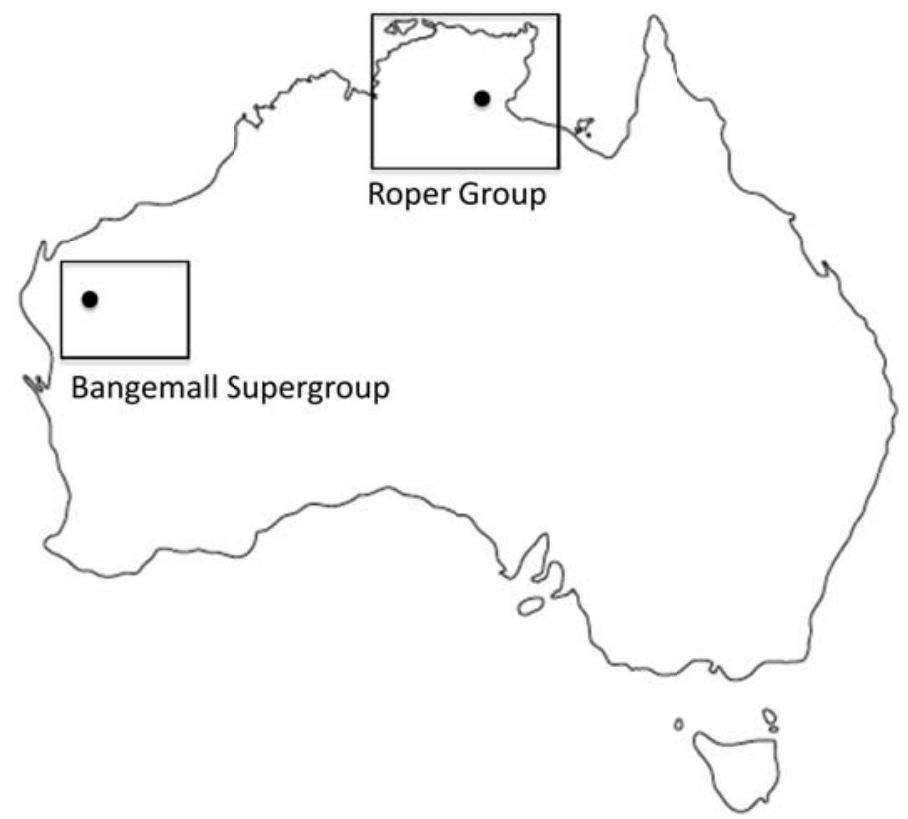

Figure 2: Locations of the Bangemall Supergroup and Roper Group (boxes) and the approximate locations of sample collection (dots). 


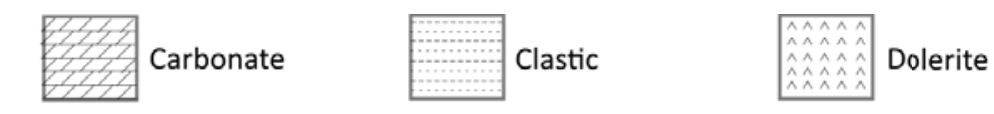
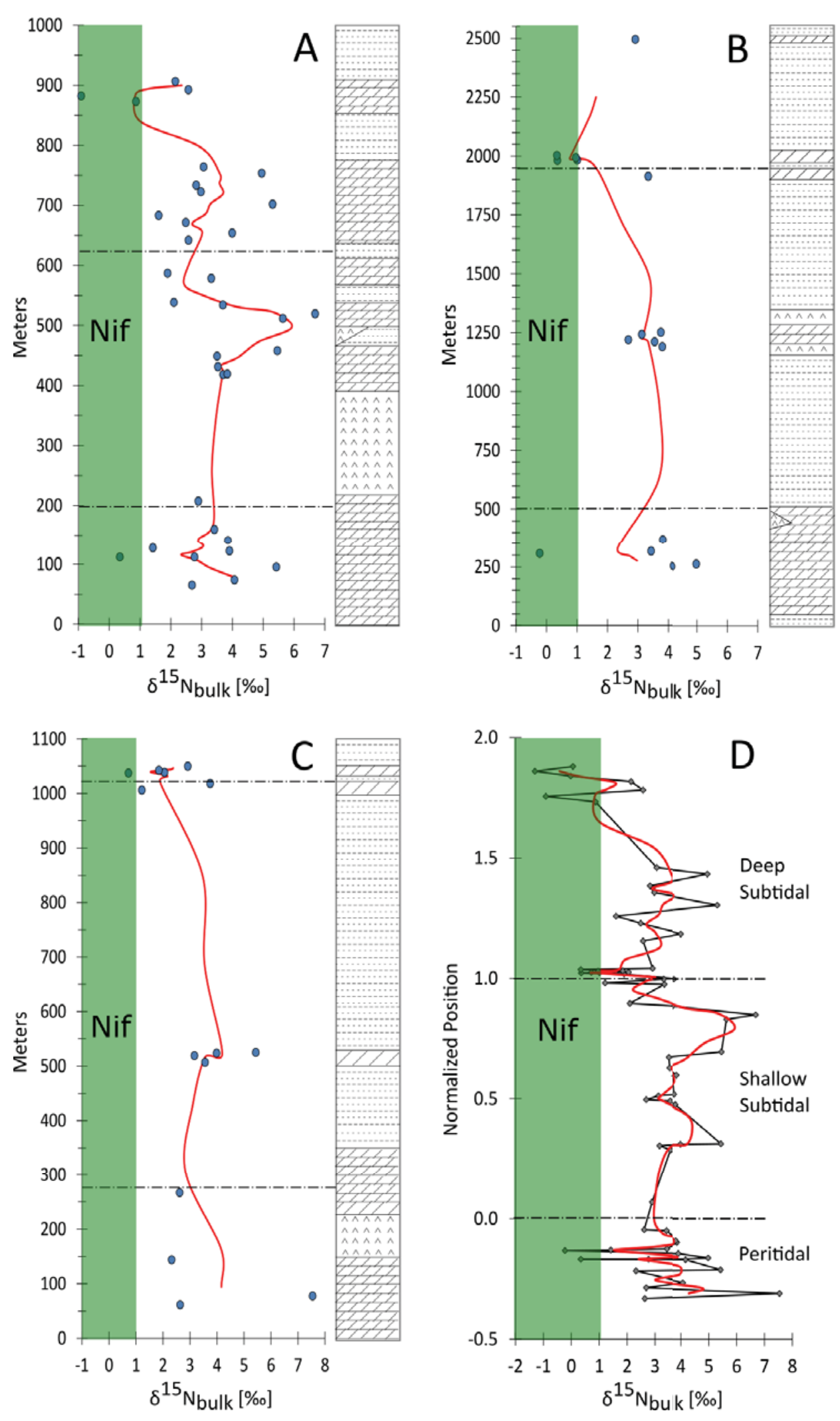
1216 Figure 3: Stratigraphic $\delta^{15} \mathrm{~N}_{\text {bulk }}$ plots of Bangemall transects (A) Fords Creek, (B) Irregully, (C) 1217 Wandarry. Depositional facies in each panel are as in panel (D), with deep subtidal above the top 1218 dot-dash line, shallow subtidal in the middle, and peritidal below the bottom dot-dash line. Panel 1219 (D) is a normalized compilation of all the Bangemall transects where the positions of each point are relative to the thickness of the shallow subtidal facies. The red line indicates the running mean over three points.

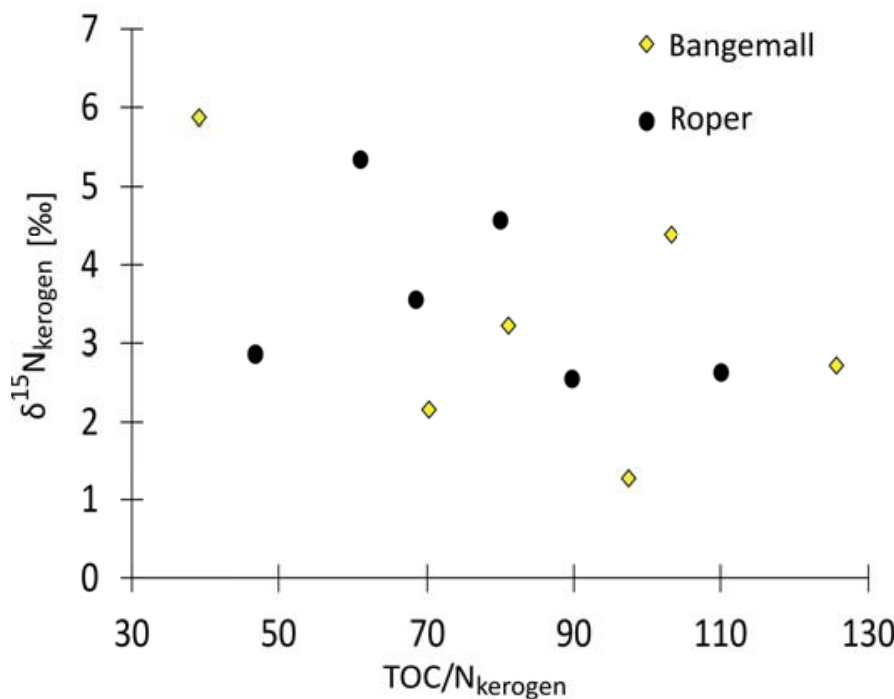

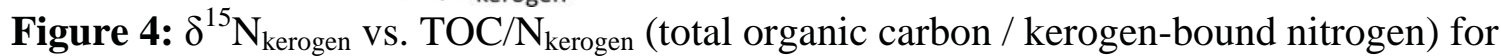
Bangemall (yellow diamonds) and Roper (black circle) samples.

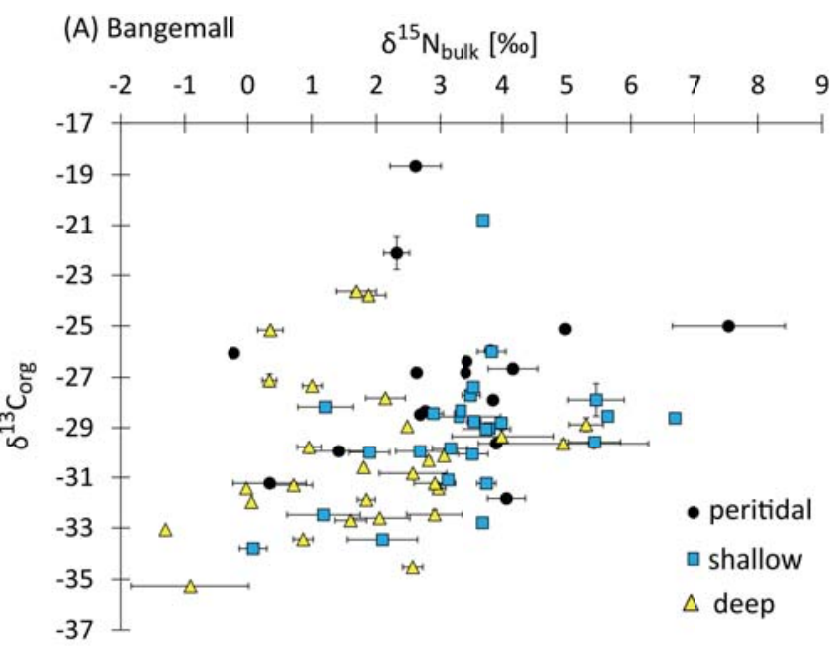

(B) Roper

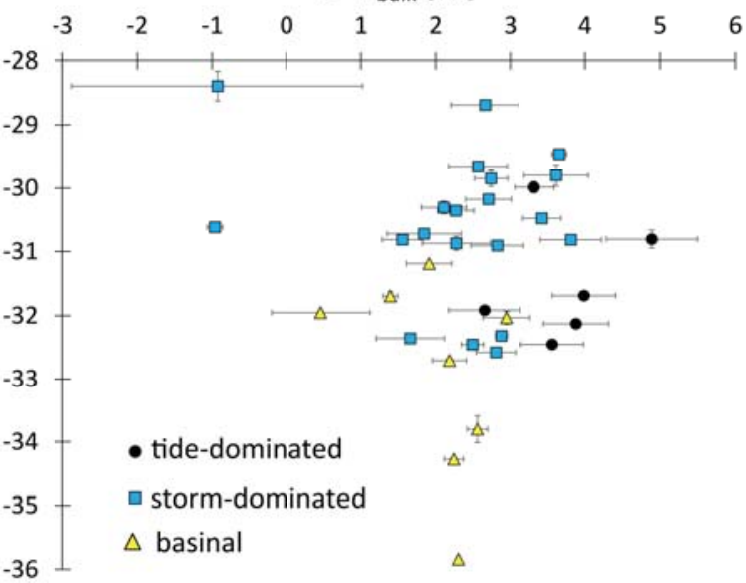

Figure 5: $\delta^{15} \mathrm{~N}_{\text {bulk }}$ plotted against $\delta^{13} \mathrm{C}_{\text {org }}$ for the Bangemall (A) and Roper (B) basins. The plot also includes those samples from the Bangemall basin that do not belong to one of the three main transects shown in Fig. 3A-C. Error bars are $\pm 1 \sigma$. 

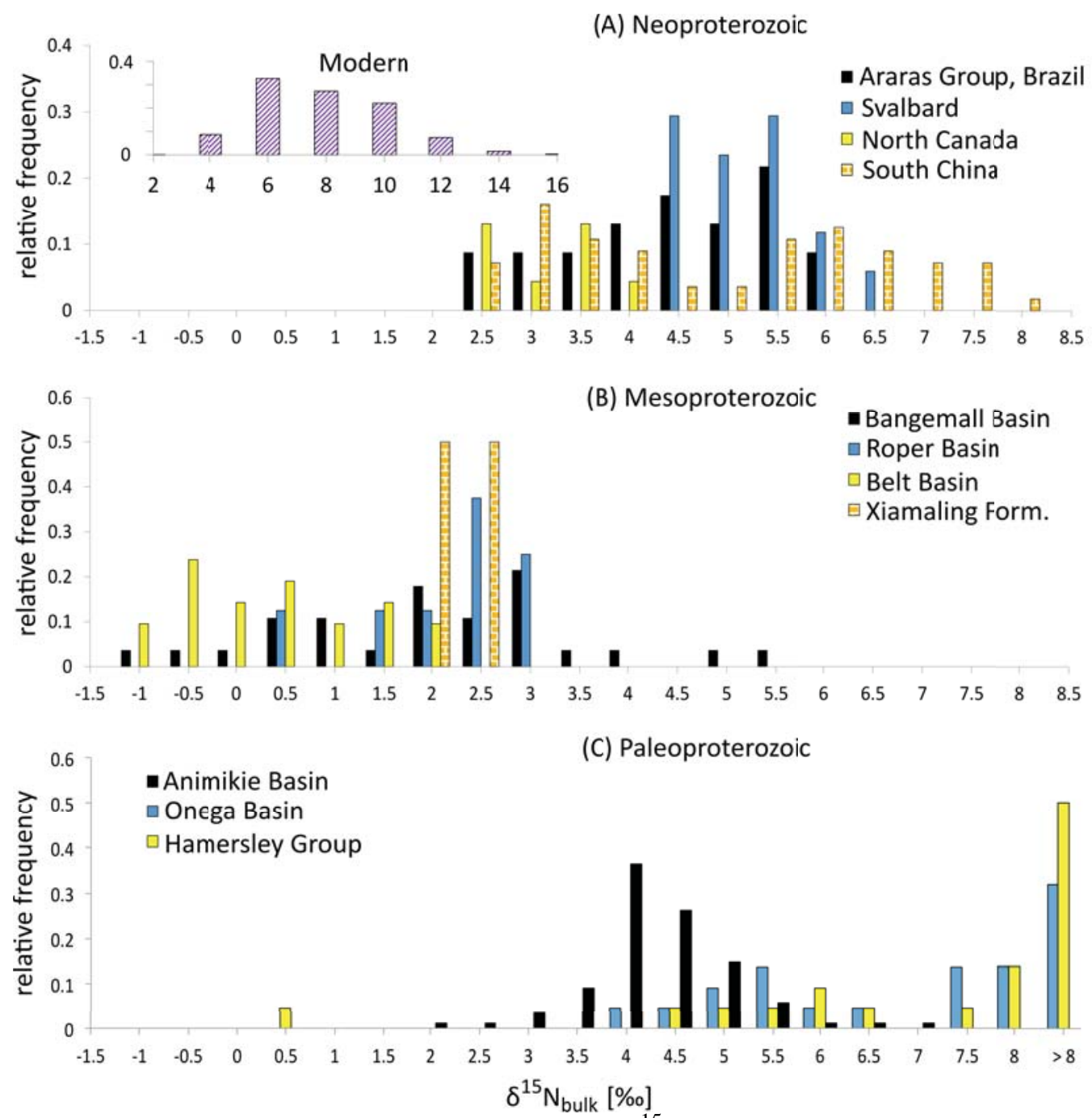

Figure 6: Histogram of Proterozoic offshore $\delta^{15} \mathrm{~N}_{\text {bulk }}$ data. (A) Neoproterozoic era (1.0-0.548 Ga) with data from Ader et al. (2014) and Kikumoto et al. (2014); (B) Mesoproterozoic era (1.6$1.0 \mathrm{Ga}$ ) with data from Stüeken (2013), Luo et al. (2015) and this study; (C) Paleoproterozoic era (2.5-1.6 Ga) with data from Busigny et al. (2013), Kump et al. (2011) and Godfrey et al. (2013). Subsets of the datasets listed above were taken to only include offshore environments: from Ader et al. (2014) the Camil, Carmelo, and Copacel sections from Brazil and all data from Svalbard and North Canada. From Kikumoto et al. (2014) all data from the Doushantuo Formation. From Stuieken (2013) data from the Newland Formation in Deep Creek. From the Bangemall and Roper of this study, "deep" and "basinal" data respectively. From Luo et al. (2015) all data. From Busigny et al. (2013) data from the Brockman Iron Formation. From Kump et al. (2011) data from above 180 meters in core depth (from 0-180m). From Godfrey et al. (2013) data from cores MGS-7 and MGS-8. The inset in panel A shows modern marine sediment data from Tesdal et al. (2013). The modern data show no correlation with water depth and are therefore not separated by facies. Paleoproterozoic data from the Aravalli Group (Papineau et al., 2009; Papineau et al., 2013) were excluded because they are of higher metamorphic grade and their depositional environment is uncertain. 
1251

1254

1255

1256

1257

1258

1259

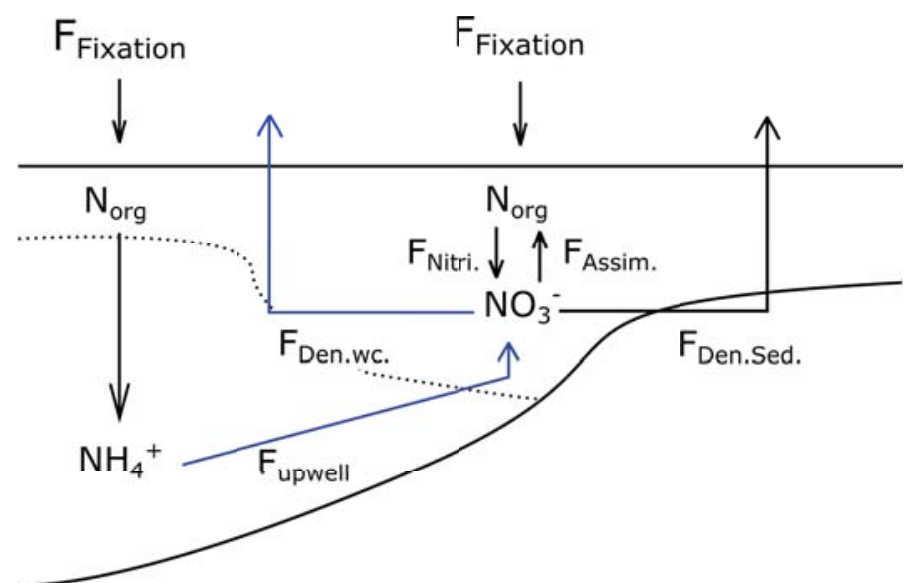

Figure 7: Cartoon of the fluxes both in and out of a shallow water nitrate reservoir as we propose for the Bangemall and Roper basins. Labels that start with F correspond to flux arrows. Blue flux arrows represent fluxes that, when varied, are most likely able to change the isotopic composition of a relatively small nitrate reservoir. All other fluxes are unlikely to change the isotopic composition of the nitrate reservoir. Flux labels are as follows: $F_{\text {fixation }}-$ nitrogen fixation flux, $F_{\text {nitri. }}$ - nitrification, $F_{\text {assim. }}$ - assimilation, $F_{\text {den.wc. }}-$ water column denitrification, $\mathrm{F}_{\text {den.sed. }}-$ sedimentary denitrification, $\mathrm{F}_{\text {upwell }}-$ upwelling. 


\section{Tables}

Table 1: List of nitrogen cycle steps that induce large isotope fractionation effects and their respective fractionation factors. Fractionations are expressed as $\delta^{15} \mathrm{~N}_{\text {substrate }}-\delta^{15} \mathrm{~N}_{\text {product }}$. References: 1.Zhang et al. (2014), 2. Casciotti (2009); 3. Frey et al. (2014); 4. Brunner et al. (2013); 5. Fulton et al. (2012); 6. Fuchsman et al. (2008); 7. Altabet \& Francois (1994); 8. Kessler et al. (2014); 9. Sigman et al. (2009a).

\begin{tabular}{|c|c|c|c|}
\hline Nitrogen cycle reaction & Fractionation factor & Ref. & Preservation potential \\
\hline $\begin{array}{l}\text { Nitrogen Fixation } \\
\left(\mathrm{N}_{2} \rightarrow \mathrm{N}_{\mathrm{org}} \rightarrow \mathrm{NH}_{4}^{+}\right)\end{array}$ & $\begin{array}{c}\text { Mo-nitrogenase: } \\
\text { +2\%o to -1\%o } \\
\text { Fe- and V- nitrogenase: } \\
\text { +6\%o to +8\% }\end{array}$ & 1 & $\begin{array}{l}\text { Preserved in sediments from } \\
\text { nitrogen-limited ecosystems [5] }\end{array}$ \\
\hline $\begin{array}{l}\text { Ammonium assimilation } \\
\left(\mathrm{NH}_{4}^{+} \rightarrow \mathrm{R}-\mathrm{NH}_{2}\right)\end{array}$ & $+14 \%$ to $+27 \%$ & 2 & $\begin{array}{l}\text { Not known to be expressed [cf. 5] } \\
\text { (Section 5.2) }\end{array}$ \\
\hline $\begin{array}{l}\text { Nitrification (ammonium } \\
\text { oxidation) } \\
\left(\mathrm{NH}_{4}^{+} \rightarrow \mathrm{NO}_{2}^{-}\right)\end{array}$ & $+14 \%$ to $+38 \%$ & 2 & $\begin{array}{l}\text { Quantitative at chemocline [6]; not } \\
\text { preserved }\end{array}$ \\
\hline $\begin{array}{l}\text { Nitrification (nitrite oxidation) } \\
\left(\mathrm{NO}_{2}^{-} \rightarrow \mathrm{NO}_{3}^{-}\right)\end{array}$ & $-12.8 \%$ & 2 & $\begin{array}{l}\text { Quantitative at chemocline [6]; not } \\
\text { preserved }\end{array}$ \\
\hline $\begin{array}{l}\text { Nitrate assimilation } \\
\left(\mathrm{NO}_{3}^{-} \rightarrow \mathrm{R}-\mathrm{NH}_{2}\right)\end{array}$ & $+5 \%$ o to $+10 \%$ o & 2 & $\begin{array}{l}\text { Usually quantitative in photic zone } \\
\text { [7]; not preserved }\end{array}$ \\
\hline $\begin{array}{l}\text { Denitrification } \\
\left(\mathrm{NO}_{3}^{-} \rightarrow \mathrm{N}_{2}\right)\end{array}$ & $+10 \%$ to $+30 \%$ & 3 & $\begin{array}{l}\text { Non-quantitative in suboxia [8,9]; } \\
\text { preserved in biomass of } \mathrm{NO}_{3}^{-} \\
\text {assimilators [7] }\end{array}$ \\
\hline $\begin{array}{l}\text { Annamox } \\
\left(\mathrm{NO}_{2}^{-}+\mathrm{NH}_{4}^{+} \rightarrow \mathrm{N}_{2}+2 \mathrm{H}_{2} \mathrm{O}\right)\end{array}$ & $\begin{array}{c}\mathrm{NO}_{2}^{-}:+16 \% \text { o } \\
\mathrm{NH}_{4}^{+}:+23 \% \text { to }+29 \% \text { o }\end{array}$ & 4 & $\begin{array}{l}\text { Probably indistinguishable from } \\
\text { denitrification [4] }\end{array}$ \\
\hline
\end{tabular}




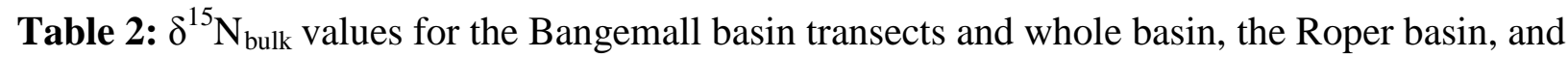
the Belt basin. Belt data are from Stüeken (2013). Parenthetical facies labels are specific to the Roper basin. Uncertainties are expressed as $\pm 1 \sigma . \mathrm{n}=$ number of samples.

\begin{tabular}{|c|c|c|c|}
\hline & $\begin{array}{c}\text { Peritidal (tide- } \\
\text { dominated platform) } \\
\delta^{15} \mathbf{N}_{\text {bulk }}\end{array}$ & $\begin{array}{c}\text { Shallow subtidal (storm- } \\
\text { dominated shelf) } \\
\delta^{15} \mathbf{N}_{\text {bulk }}\end{array}$ & $\begin{array}{c}\text { Deep subtidal } \\
\text { (basinal) } \delta^{15} N_{\text {bulk }}\end{array}$ \\
\hline \multicolumn{4}{|l|}{ Bangemall basin: } \\
\hline Fords Creek & $\begin{array}{c}3.1 \% \text { } \pm 1.5 \% \text { o } \\
(\mathrm{n}=10)\end{array}$ & $\begin{array}{c}3.9 \% \text { o } \pm 1.4 \% o \\
(n=12)\end{array}$ & $\begin{array}{c}2.7 \% \text { } \pm 1.6 \% \\
(n=13)\end{array}$ \\
\hline Irregully Creek & $\begin{array}{c}3.2 \% \text { o } \pm 2.0 \% \text { o } \\
(n=5)\end{array}$ & $\begin{array}{c}3.4 \% \text { o } \pm 0.4 \% \text { o } \\
(\mathrm{n}=6)\end{array}$ & $\begin{array}{c}1.1 \% \text { o } \pm 1.1 \% \text { o } \\
(\mathrm{n}=5)\end{array}$ \\
\hline Wandarry Creek & $\begin{array}{c}3.8 \% \text { } \pm 2.5 \% \text { o } \\
(\mathrm{n}=4)\end{array}$ & $\begin{array}{c}3.5 \% \text { o } \pm 1.4 \% \text { o } \\
(\mathrm{n}=6)\end{array}$ & $\begin{array}{c}1.9 \% \text { o } \pm 0.9 \% \text { o } \\
(\mathrm{n}=4)\end{array}$ \\
\hline All & $\begin{array}{c}3.3 \% \text { o } \pm 1.8 \% \text { o } \\
(n=18)\end{array}$ & $\begin{array}{c}3.4 \% \text { o } \pm 1.4 \% \text { o } \\
(n=26)\end{array}$ & $\begin{array}{c}1.8 \% \text { o } \pm 1.6 \% \text { o } \\
(\mathrm{n}=28)\end{array}$ \\
\hline Roper basin: & $\begin{array}{c}3.7 \% \text { o } \pm 0.8 \% \text { o } \\
(\mathrm{n}=6)\end{array}$ & $\begin{array}{c}2.3 \% \text { o } \pm 1.3 \% \\
(n=20)\end{array}$ & $\begin{array}{c}2.0 \% \text { o } \pm 0.8 \% \text { o } \\
(\mathrm{n}=8)\end{array}$ \\
\hline Belt basin: & $\begin{array}{c}3.7 \% \text { o } \pm 1.4 \% \text { o } \\
(\mathrm{n}=13)\end{array}$ & $\begin{array}{c}1.5 \% \text { o } \pm 1.2 \% \text { o } \\
(\mathrm{n}=35)\end{array}$ & $\begin{array}{c}0.1 \% \text { o } \pm 0.9 \% \text { o } \\
(\mathrm{n}=21)\end{array}$ \\
\hline
\end{tabular}

Table 3: $\delta^{13} \mathrm{C}_{\text {org }}$ in the Bangemall, Roper, and Belt basins. Parenthetical facies labels are specific to the Roper basin. Data from the Jixian basin are taken from Guo et al. (2013). Uncertainties are expressed as $\pm 1 \sigma . \mathrm{n}=$ number of samples.

\begin{tabular}{|c|c|c|c|}
\hline & $\begin{array}{c}\text { Peritidal } \\
\text { (tide-dominated } \\
\text { platform) } \\
\delta^{13} C_{\text {org }}\end{array}$ & $\begin{array}{c}\text { Shallow subtidal } \\
\text { (storm-dominated shelf) } \\
\qquad \delta^{13} \mathrm{C}_{\text {org }}\end{array}$ & $\begin{array}{c}\text { Deep subtidal } \\
\text { (basinal) } \\
\delta^{13} C_{\text {org }}\end{array}$ \\
\hline Bangemall basin & $\begin{array}{c}-27.0 \% \text { o } \pm 3.2 \% \\
(\mathrm{n}=18)\end{array}$ & $\begin{array}{c}-29.2 \% \text { o } \pm 2.6 \% \text { } \\
(n=26)\end{array}$ & $\begin{array}{c}-30.2 \% \circ \pm 2.9 \% \\
(n=28)\end{array}$ \\
\hline Roper basin & $\begin{array}{c}-31.5 \% \text { o } \pm 0.9 \% \text { o } \\
n=6\end{array}$ & $\begin{array}{c}-30.6 \% \text { o } \pm 1.2 \% \text { } \\
n=20\end{array}$ & $\begin{array}{c}-32.9 \% \text { } \pm 1.6 \% \\
n=8\end{array}$ \\
\hline Belt basin & $\begin{array}{c}-32.2 \% \text { } \pm 1.2 \% \text { } \\
(n=13)\end{array}$ & $\begin{array}{c}-30.1 \% \text { } \pm 1.9 \% \text { } \\
(n=35)\end{array}$ & $\begin{array}{c}-22.9 \% \circ \pm 2.9 \% \\
(n=21)\end{array}$ \\
\hline Jixian basin & $\begin{array}{c}-28.2 \% \text { o } \pm 1.6 \% \text { o } \\
(\mathrm{n}=191)\end{array}$ & $\begin{array}{c}-30.8 \% \text { o } \pm 2.0 \% \text { } \\
(n=61)\end{array}$ & $\mathrm{n} / \mathrm{a}$ \\
\hline
\end{tabular}




\section{APPENDIX}

Table A1: New data from the Bangemall Group

\begin{tabular}{|c|c|c|c|c|c|c|c|c|c|c|c|}
\hline Sample ID & $\begin{array}{c}\text { Position } \\
\text { [m] }\end{array}$ & Facies & $\begin{array}{c}\text { TN } \\
\text { [ppm] }\end{array}$ & $\begin{array}{c}\delta^{15} N_{\text {bulk }} \\
{[\% \text { o] }}\end{array}$ & $\begin{array}{c}1 \sigma \delta^{15} \mathrm{~N} \\
{[\% \circ]}\end{array}$ & $\begin{array}{c}\text { TOC } \\
{[\mathrm{ppm}]}\end{array}$ & $\begin{array}{c}\delta^{13} C_{\text {org }} \\
{[\% \text { o] }}\end{array}$ & $\begin{array}{c}1 \sigma \delta^{13} \mathrm{C} \\
{[\% \circ]}\end{array}$ & $\mathrm{C} / \mathrm{N}$ [atomic] & $\delta^{13} C_{\text {carb }}[\%$ ] & $\begin{array}{c}\text { Carb } \\
\text { [\%] }\end{array}$ \\
\hline \multicolumn{12}{|l|}{ Fords Creek } \\
\hline 89023 & 73.95 & peritidal & 46 & 4.1 & 0.30 & 299 & -31.8 & 0.00 & 7.6 & 0.8 & 72.3 \\
\hline 89025 & 95.7 & peritidal & 1719 & 5.4 & & 4249 & -29.6 & & 2.9 & 0.4 & 89.1 \\
\hline 89028 & 112.5 & peritidal & 50 & 0.3 & 0.57 & 3454 & -31.2 & 0.11 & 81.0 & & \\
\hline 89029 & 122.7 & peritidal & 582 & 3.9 & & 1226 & -29.6 & & 2.5 & 1.2 & 79.1 \\
\hline 89036 & 160.1 & peritidal & 661 & 3.4 & & 2028 & -26.8 & & 3.6 & -0.3 & 89.7 \\
\hline 89064 & 207.63 & shallow & 10 & 2.9 & 0.15 & 415 & -28.4 & 0.00 & 50.9 & -0.1 & 90.9 \\
\hline 89071 & 418.32 & shallow & 244 & 3.7 & 0.03 & 7100 & -20.8 & 0.05 & 34.0 & -0.9 & 86.9 \\
\hline 89072 & 419.34 & shallow & 127 & 3.8 & 0.22 & 5005 & -26.0 & 0.17 & 45.9 & -0.5 & 32.2 \\
\hline 89074 & 431.39 & shallow & 64 & 3.5 & 0.25 & 1705 & -30.1 & 0.03 & 30.9 & -1.2 & 22.8 \\
\hline 89075 & 449.08 & shallow & 22 & 3.5 & 0.15 & 291 & -27.7 & 0.13 & 15.7 & -0.6 & 84.2 \\
\hline 89081 & 511.94 & shallow & 217 & 5.6 & & 7094 & -28.5 & & 38.2 & -1 & 95.4 \\
\hline 89083 & 519.53 & shallow & 3390 & 6.7 & & 17847 & -28.6 & & 6.1 & -0.7 & \\
\hline 89086 & 578.71 & shallow & 81 & 3.3 & 0.66 & 850 & -28.6 & 0.13 & 12.2 & 0.4 & 96.7 \\
\hline 89090 & 642.17 & deep & 58 & 2.6 & 0.53 & 1705 & -30.8 & 0.05 & 34.6 & 0.1 & 77.6 \\
\hline 89091 & 653.91 & deep & 66 & 4.0 & 0.81 & 213 & -29.3 & 0.27 & 3.8 & -0.7 & 81.5 \\
\hline 89093 & 671.66 & deep & 124 & 2.5 & & 3261 & -28.9 & & 30.7 & -0.8 & 97.0 \\
\hline 89094 & 683.4 & deep & 94 & 1.6 & 0.24 & 2134 & -32.7 & 0.05 & 26.5 & -1.1 & \\
\hline 89095 & 702.15 & deep & 47 & 5.3 & 0.26 & 377 & -28.9 & 0.27 & 9.3 & -1.1 & 82.3 \\
\hline 89097 & 722.85 & deep & 57 & 3.0 & 0.11 & 459 & -31.4 & 0.14 & 9.4 & -1 & 75.9 \\
\hline 89098 & 733.77 & deep & 68 & 2.8 & 0.00 & 447 & -30.3 & 0.11 & 7.7 & -0.8 & 71.6 \\
\hline 89100 & 753.72 & deep & 48 & 4.9 & 1.32 & 701 & -29.6 & 0.15 & 17.0 & -1.2 & 91.2 \\
\hline 89102 & 764.08 & deep & 66 & 3.1 & 0.04 & 414 & -30.1 & 0.08 & 7.3 & -1.3 & 86.1 \\
\hline 89106 & 873 & deep & 64 & 0.9 & 0.15 & 4107 & -33.5 & 0.01 & 74.6 & 0.2 & 57.9 \\
\hline 89107 & 882.4 & deep & 21 & -0.9 & 0.93 & 999 & -35.3 & 0.02 & 55.1 & 0.1 & 63.2 \\
\hline 89108 & 892.79 & deep & 90 & 2.6 & 0.16 & 9569 & -34.5 & 0.02 & 123.6 & 1.1 & 46.0 \\
\hline
\end{tabular}




\begin{tabular}{|c|c|c|c|c|c|c|c|c|c|c|c|}
\hline 89110 & 906.7 & deep & 19 & 2.1 & 0.31 & 127 & -27.8 & 0.08 & 7.8 & -0.8 & \\
\hline 89122 & 587.2 & shallow & 46 & 1.9 & 0.32 & 1963 & -30.0 & 0.04 & 49.4 & -0.6 & \\
\hline 89123 & 538.5 & shallow & 35 & 2.1 & 0.55 & 3654 & -33.5 & 0.03 & 122.7 & -1.1 & 59.5 \\
\hline 89125 & 458.2 & shallow & 265 & 5.5 & 0.43 & 456 & -27.9 & 0.65 & 2.0 & 0.3 & 84.6 \\
\hline 89127 & 141.3 & peritidal & 86 & 3.9 & & 2157 & -27.9 & & 29.3 & 0.4 & 94.4 \\
\hline 89130 & 65.4 & peritidal & 78 & 2.7 & & 1908 & -28.5 & & 28.7 & 0.8 & 97.5 \\
\hline 90049 & 534.15 & shallow & 804 & 3.7 & & 3639 & -32.8 & & 5.3 & -0.5 & 85.5 \\
\hline $89028 \mathrm{~A}$ & 112.5 & peritidal & 1164 & 2.8 & & 3058 & -28.3 & & 3.1 & 0.8 & \\
\hline 89030D & 127.9 & peritidal & 52 & 1.4 & 0.46 & 3273 & -29.9 & 0.08 & 73.9 & 0.4 & 92.6 \\
\hline \multicolumn{12}{|l|}{ Irregully } \\
\hline 89165 & 254.91 & peritidal & 430 & 4.2 & 0.39 & 2190 & -26.7 & 0.23 & 5.9 & -0.7 & 88.1 \\
\hline 89166 & 265.24 & peritidal & 88 & 5.0 & & 2749 & -25.1 & & 36.6 & -0.2 & 95.8 \\
\hline 89174 & 308.06 & peritidal & 66 & -0.2 & 0.07 & 1176 & -26.0 & 0.12 & 20.8 & 0 & 96.8 \\
\hline 89178 & 317.94 & peritidal & 89 & 3.4 & & 3905 & -26.4 & & 51.0 & 0.2 & 96.8 \\
\hline 89197 & 369.81 & peritidal & 58 & 3.8 & 0.02 & 2348 & -25.9 & 0.05 & 47.1 & -0.3 & 90.5 \\
\hline 89222 & 1190.9 & shallow & 69 & 3.8 & 0.00 & 1413 & -29.0 & & 23.9 & -2.1 & 73.7 \\
\hline 89225 & 1211.94 & shallow & 54 & 3.5 & 0.01 & 688 & -27.4 & 0.21 & 14.8 & 0.6 & 56.0 \\
\hline 89226 & 1220.24 & shallow & 49 & 2.7 & 0.38 & 664 & -30.0 & 0.05 & 15.7 & 0.2 & \\
\hline 89231 & 1243.19 & shallow & 905 & 3.1 & & 953 & -31.1 & & 1.2 & -0.7 & 69.8 \\
\hline 89232 & 1252.45 & shallow & 72 & 3.7 & 0.15 & 1467 & -31.2 & 0.02 & 23.9 & -0.8 & \\
\hline 90010 & 1914.35 & shallow & 374 & 3.3 & & 23856 & -28.3 & & 74.5 & -3.9 & 99.4 \\
\hline 90017 & 1982.17 & deep & 104 & 0.4 & 0.20 & 292 & -25.2 & 0.10 & 3.3 & -0.3 & 46.8 \\
\hline 90018 & 1983.53 & deep & 272 & 1.0 & 0.15 & 259 & -27.3 & 0.04 & 1.1 & -1.3 & \\
\hline 90019 & 1993.14 & deep & 389 & 1.0 & 0.19 & 2654 & -29.8 & 0.08 & 8.0 & 1.6 & \\
\hline 90020 & 2003.25 & deep & 244 & 0.3 & 0.11 & 498 & -27.1 & 0.26 & 2.4 & -0.7 & 52.5 \\
\hline 90032 & 2496.22 & deep & 398 & 2.9 & 0.44 & 2008 & -32.5 & 0.18 & 5.9 & -2.8 & 68.5 \\
\hline \multicolumn{12}{|l|}{ Wandarry } \\
\hline 90062 & 61.64 & peritidal & 61 & 2.6 & 0.04 & 1346 & -26.8 & 0.01 & 25.8 & -0.7 & 94.6 \\
\hline
\end{tabular}




\begin{tabular}{|c|c|c|c|c|c|c|c|c|c|c|c|}
\hline 90088 & 77.72 & peritidal & 495 & 7.5 & 0.89 & 2604 & -25.0 & 0.05 & 6.1 & 0 & 77.9 \\
\hline 89138 & 143.9 & peritidal & 8 & 2.3 & 0.20 & 507 & -22.1 & 0.65 & 73.9 & 0.5 & 38.5 \\
\hline 90070 & 267.17 & peritidal & 5 & 2.6 & 0.40 & 432 & -18.7 & 0.03 & 105.5 & -0.4 & 13.1 \\
\hline 90080 & 507 & shallow & 35 & 3.6 & 0.11 & 423 & -28.7 & 0.01 & 13.9 & -1.1 & 89.1 \\
\hline 90078 & 519.45 & shallow & 33 & 3.2 & 0.29 & 741 & -29.8 & 0.03 & 26.2 & -1.4 & 89.9 \\
\hline 90081 & 524 & shallow & 39 & 4.0 & & 586 & -28.8 & & 17.7 & -1.2 & 94.4 \\
\hline 90079 & 525.25 & shallow & 4187 & 5.4 & 0.40 & 9907 & -29.6 & 0.11 & 2.8 & -1.1 & 93.8 \\
\hline 90086 & 1006.4 & shallow & 20 & 1.2 & 0.43 & 304 & -28.2 & 0.21 & 17.5 & 0.5 & 89.9 \\
\hline 90087 & 1018.45 & shallow & 671 & 3.7 & 0.38 & 5767 & -29.1 & 0.08 & 10.0 & 1.3 & 92.5 \\
\hline 90085 & 1037.75 & deep & 690 & 0.7 & 0.30 & 1015 & -31.3 & 0.10 & 1.7 & 1.2 & 70.3 \\
\hline 90084 & 1038.8 & deep & 116 & 2.1 & 0.47 & 537 & -32.6 & 0.06 & 5.4 & -0.6 & 57.0 \\
\hline 90082 & 1042.75 & deep & 94 & 1.8 & 0.14 & 442 & -31.9 & 0.01 & 5.5 & -0.1 & 46.4 \\
\hline 90083 & 1050 & deep & 527 & 2.9 & 0.32 & 648 & -31.2 & 0.05 & 1.4 & -0.7 & 63.3 \\
\hline \multicolumn{12}{|l|}{ Other } \\
\hline 90074 & & shallow & 41 & 0.1 & 0.22 & 5272 & -33.8 & 0.03 & 150.4 & & \\
\hline 89063 & & deep & 71 & 0.1 & & 4433 & -32.0 & & 72.4 & & 7.1 \\
\hline 89066 & & deep & 52 & -1.3 & & 26252 & -33.1 & & & & 6.9 \\
\hline 89067 & & deep & 90 & 0.0 & & 9119 & -31.4 & & 118.8 & & 7.7 \\
\hline 90016 & & deep & 139 & 1.8 & 0.04 & 7342 & -30.6 & 0.05 & 61.7 & & \\
\hline 89050 & & deep & 95 & 1.7 & 0.31 & 306 & -23.6 & 0.07 & 3.7 & -1.8 & 42.2 \\
\hline 89051 & & deep & 80 & 1.9 & 0.27 & 277 & -23.8 & 0.17 & 4.0 & -2.2 & 57.3 \\
\hline
\end{tabular}


Table A2: New data from the Roper Group. Facies abbreviations: t.d shoreline = tide-dominated shoreline; sand.d shelf = sand-dominated shelf; s.d shelf = storm-dominated shelf; c.s platform = coastal sand platform.

\begin{tabular}{|c|c|c|c|c|c|c|c|c|c|c|c|}
\hline Sample ID & $\begin{array}{c}\text { Position } \\
\text { [m] }\end{array}$ & Facies & $\begin{array}{c}\text { TN } \\
\text { [ppm] }\end{array}$ & $\begin{array}{c}\delta^{15} N_{\text {bulk }} \\
{[\% \text { o] }}\end{array}$ & $\begin{array}{c}1 \sigma \delta^{15} N \\
{[\% o]}\end{array}$ & $\begin{array}{c}\text { TOC } \\
{[\mathrm{ppm}]}\end{array}$ & $\begin{array}{c}\delta^{13} C_{\text {org }} \\
{[\% \text { ] }}\end{array}$ & $\begin{array}{c}1 \sigma \delta^{13} \mathrm{C} \\
{[\% \text { ] }}\end{array}$ & $\begin{array}{c}\mathrm{C} / \mathrm{N} \\
\text { [atomic] }\end{array}$ & $\begin{array}{c}\text { Carb } \\
(\%)\end{array}$ & Formation \\
\hline \multicolumn{12}{|l|}{ Amoco 82/3 } \\
\hline A101.5 & 101.5 & t.d shoreline & 173 & 2.7 & 0.48 & 5002 & -31.9 & 0.05 & 33.7 & 8.5 & Bessie Creek \\
\hline A178.0 & 178 & sand.d shelf & 36 & 4.9 & 0.61 & 768 & -30.8 & 0.14 & 25.0 & 37.1 & Jalboi \\
\hline A311.3 & 311.3 & s.d shelf & 47 & -1.0 & 0.11 & 978 & -30.6 & 0.01 & 24.2 & 20.8 & Crawford \\
\hline A331.8 & 331.8 & s.d shelf & 165 & 2.6 & 0.39 & 1434 & -29.7 & 0.05 & 10.1 & 21.5 & Crawford \\
\hline A375.1 & 375.1 & s.d shelf & 199 & 2.8 & 0.36 & 2369 & -30.9 & 0.03 & 13.9 & 28.2 & Crawford \\
\hline A391.0 & 391 & s.d shelf & 225 & 3.8 & 0.41 & 3992 & -30.8 & 0.01 & 20.7 & 15.1 & Crawford \\
\hline A407.65 & 407.65 & s.d shelf & 24 & -0.9 & 1.95 & 336 & -28.4 & 0.23 & 16.2 & 18.1 & Crawford \\
\hline A544.1 & 544.1 & s.d shelf & 315 & 2.7 & 0.31 & 2593 & -30.2 & 0.07 & 9.6 & 27.7 & Maironu \\
\hline A549.25 & 549.25 & s.d shelf & 250 & 3.6 & 0.43 & 1191 & -29.8 & 0.17 & 5.6 & 27.1 & Maironu \\
\hline A561.05 & 561.05 & s.d shelf & 214 & 2.7 & 0.46 & 596 & -28.7 & 0.03 & 3.2 & 29.2 & Maironu \\
\hline \multicolumn{12}{|l|}{ Broughton 1} \\
\hline BR1 23.4 & 23.4 & s.d shelf & 429 & 2.1 & 0.30 & 794 & -30.3 & 0.10 & 2.2 & 21.0 & Corcoran \\
\hline BR1 34.5 & 34.5 & s.d shelf & 222 & 2.3 & 0.24 & 686 & -30.4 & 0.03 & 3.6 & 12.6 & Corcoran \\
\hline BR1 42.3 & 42.3 & s.d shelf & 253 & 2.3 & 0.45 & 1006 & -30.9 & 0.11 & 4.6 & 15.9 & Corcoran \\
\hline BR1 52.35 & 52.35 & s.d shelf & 179 & 1.6 & 0.27 & 1023 & -30.8 & 0.08 & 6.7 & 30.4 & Corcoran \\
\hline BR1 69.0 & 69 & s.d shelf & 289 & 2.7 & 0.22 & 774 & -29.8 & 0.13 & 3.1 & 21.4 & Corcoran \\
\hline BR1 122.4 & 122.4 & c.s platform & 518 & 3.3 & 0.27 & 1041 & -30.0 & 0.09 & 2.3 & 33.5 & Hodgsen ss \\
\hline BR1 136.8 & 136.8 & c.s platform & 99 & 4.0 & 0.42 & 2122 & -31.7 & 0.07 & 24.9 & 14.4 & Hodgsen ss \\
\hline BR1 150.45 & 150.45 & s.d shelf & 217 & 1.8 & 0.50 & 1328 & -30.7 & 0.05 & 7.1 & 18.9 & Crawford \\
\hline BR1 244.7 & 244.7 & s.d shelf & 227 & 3.7 & 0.10 & 914 & -29.5 & 0.02 & 4.7 & 18.7 & Maironu \\
\hline \multicolumn{12}{|c|}{ Golden Grove 1} \\
\hline GG1 48.75 & 48.75 & basinal & 160 & 0.5 & 0.66 & 3300 & -32.0 & 0.04 & 24.1 & 25.9 & Velkerri \\
\hline GG1 53.2 & 53.2 & basinal & 326 & 1.4 & 0.10 & 2373 & -31.7 & 0.07 & 8.5 & 19.9 & Velkerri \\
\hline
\end{tabular}




\begin{tabular}{|c|c|c|c|c|c|c|c|c|c|c|c|}
\hline GG1 229.50 & 229.5 & s.d shelf & 435 & 2.9 & 0.08 & 1620 & -32.3 & 0.01 & 4.3 & 16.1 & Corcoran \\
\hline GG1 370.70 & 370.7 & s.d shelf & 346 & 3.4 & 0.25 & 978 & -30.5 & 0.02 & 3.3 & 8.9 & Corcoran \\
\hline \multicolumn{12}{|l|}{ Urapunga 4} \\
\hline U4 26.4 & 26.4 & C.s platform & 544 & 3.6 & 0.42 & 13617 & -32.5 & 0.07 & 29.2 & 31.2 & McMinn \\
\hline U4 33.2 & 33.2 & c.s platform & 79 & 3.9 & 0.43 & 3779 & -32.1 & 0.00 & 56.0 & 44.2 & McMinn \\
\hline U4 82.25 & 82.25 & basinal & 375 & 2.9 & 0.32 & 5092 & -32.0 & 0.10 & 15.9 & 19.8 & Velkerri \\
\hline U4 124.0 & 124 & basinal & 475 & 2.6 & 0.14 & 23859 & -33.8 & 0.21 & 58.6 & 22.2 & Velkerri \\
\hline U4 421.5 & 421.5 & s.d shelf & 266 & 1.7 & 0.46 & 1908 & -32.4 & 0.05 & 8.4 & 25.5 & Corcoran \\
\hline U4 431.0 & 431 & s.d shelf & 432 & 2.5 & 0.15 & 3450 & -32.5 & 0.06 & 9.3 & 14.5 & Corcoran \\
\hline U4 440.95 & 440.95 & s.d shelf & 285 & 2.8 & 0.26 & 1768 & -32.6 & 0.04 & 7.2 & 16.9 & Corcoran \\
\hline U4 485.1 & 485.1 & basinal & 227 & 1.9 & 0.30 & 1418 & -31.2 & 0.01 & 7.3 & 36.8 & Corcoran \\
\hline \multicolumn{12}{|l|}{ Other } \\
\hline Velkerri_CS11 & & basinal & 1409 & 2.2 & 0.13 & 52629 & -34.3 & 0.01 & 43.6 & & Velkerri \\
\hline Velkerri_CS17 & & basinal & 1287 & 2.3 & 0.03 & 62685 & -35.8 & 0.01 & 56.8 & & Velkerri \\
\hline Velkerri_CS9 & & basinal & 1531 & 2.2 & 0.23 & 42574 & -32.7 & 0.03 & 32.4 & & Velkerri \\
\hline
\end{tabular}


Table A3: Kerogen data. Included are data from both the Roper and the Bangemall groups

\begin{tabular}{|c|c|c|c|c|c|}
\hline Sample ID & $\delta^{15} N_{\text {kerogen }}[\%$ o] & $1 \sigma[\% o]$ & $\begin{array}{l}\mathbf{C} / \mathbf{N}_{\text {ker }} \\
\text { [atomic] }\end{array}$ & $\mathbf{F}\left(\mathbf{N}_{\mathrm{ker}}\right)[\%]$ & $\mathrm{F}\left(\mathrm{N}_{\text {sil }}\right)[\%]^{*}$ \\
\hline \multicolumn{6}{|l|}{ Bangemall: } \\
\hline 90050 & 2.73 & & 126 & & \\
\hline 90079 & 5.87 & 0.30 & 39.1 & 71 & 29 \\
\hline 89138 & 4.38 & 0.06 & 103.2 & & \\
\hline 89094 & 2.16 & 0.20 & 70.2 & 40 & 60 \\
\hline 89036 & 3.22 & & 81.1 & 44 & 56 \\
\hline 89028 & 1.27 & 0.30 & 97.4 & 86 & 14 \\
\hline \multicolumn{6}{|l|}{ Roper: } \\
\hline A391.0 & 4.57 & 0.55 & 80.1 & 24 & 76 \\
\hline BR1 23.4 & 2.55 & & 89.8 & 2 & 98 \\
\hline BR1 244.7 & 2.63 & & 110.1 & 4 & 96 \\
\hline GG1 53.2 & 2.86 & & 46.9 & 18 & 82 \\
\hline U4 33.2 & 5.34 & 0.12 & 61.0 & 66 & 34 \\
\hline U4 82.25 & 3.55 & 0.42 & 68.5 & 23 & 77 \\
\hline
\end{tabular}

${ }^{*}$ To calculate the fraction (F) of silicate and kerogen bound nitrogen:

$$
\begin{gathered}
\left(\frac{N[\%]}{C[\%]}\right)_{\text {kerogen }} * \text { TOC }[\%]_{\text {bulk }}=N[\%]_{\text {kerogen }} \\
\frac{N[\%]_{\text {kerogen }}}{N[\%]_{\text {bulk }}}=F_{\text {kerogen }} \\
1-F_{\text {kerogen }}=F_{\text {Silicate }}
\end{gathered}
$$

